\title{
A Case Study on the Positive Effects of Smartphone Usage in Postgraduate Education
}

\author{
Erinç KARATAȘ*a
}

\begin{tabular}{l} 
Article Info \\
\hline DOI: $10.14686 /$ buefad.402975 \\
\hline Article History: \\
Received: $\quad 07.03 .2018$ \\
Accepted: $\quad 17.05 .2018$ \\
Published: $\quad 30.06 .2018$ \\
\hline Keywords: \\
Smartphone usage, \\
Postgraduate education, \\
Case study. \\
\hline Article Type: \\
Research Article \\
\end{tabular}

\begin{abstract}
Smartphones have become a part of the individuals in all societies. This is also true for students. Studies on the effects of the use of smart devices in educational environments, especially during the course, have begun to attract the attention of researchers. The aim of this research is to seek answer to the question of the positive effects of the use of smartphones in the education processes of graduate students. In the case study, which was designed as a Type 1 study, 29 students who received masters training in 10 different departments in the Educational Sciences Institute of one of Ankara's established universities were involved. According to the opinions obtained through the feedback form from participants who declared that most of them use a smartphone for more than 4 hours a day, it was determined that they used these devices for searching the subject or the term of the course, academic research, following course materials, taking notes via photographs or voice notes, communicating with peers and instructors, and so on. Besides smartphones are also used for actions like notifications that are not relevant to the course, or clock control because student is bored.
\end{abstract}

\section{Lisansüstü Eğitimde Akıllı Cep Telefonu Kullanımının Olumlu Etkileri Üzerine Bir Durum Çalışması}

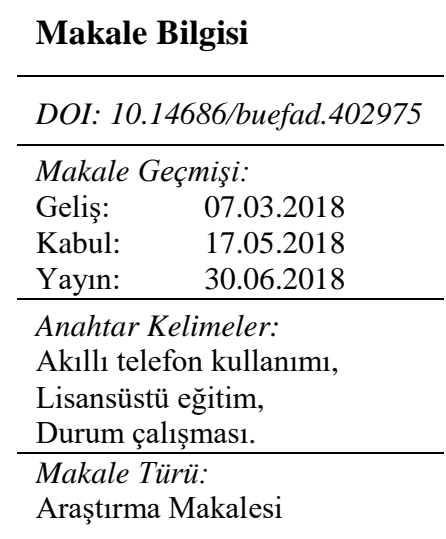

\section{$\ddot{\mathbf{O z}}$}

Tüm toplumlara bakıldığında akıllı cep telefonları bireylerin birer parçası haline gelmiştir. Bu durum öğrenciler için de geçerlidir. Eğitim ortamlarında özellikle de ders sırasında akıllı cihazların kullanımının etkileri üzerine yapılan çalışmalar, araştırmacıların dikkatini çekmeye başlamıştır. Bu araştırmanın amacı, yüksek lisans öğrencilerinin eğitim süreçlerinde akıllı cep telefonu kullanımının olumlu etkilerine yönelik görüşleri nelerdir sorusuna cevap aramaktır. Durum çalışması Tip 1 olarak desenlenen araştırmada, Ankara'nın köklü üniversitelerinden birinin Eğitim Bilimleri Enstitüsünde yer alan 10 farklı anabilim dalında yüksek lisans eğitimi alan 29 öğrenci ile çalışılmıştır. Çoğunluğunun günde 4 saatten fazla akıllı cep telefonu kullandığını beyan eden katılımcilardan görüş formu yoluyla elde edilen görüşlere göre, bu cihazları daha çok derste geçen konu ya da terimi araştırma, akademik araştırma, ders materyallerini takip etme, fotoğraf ya da sesli not özelliği ile ders notu alma, akran ve öğretim elemanı ile iletişim amaçlı kullandıkları gibi, sıkılma nedeniyle ders ile ilgisi olmayan bildirimlerin ya da saatin kontrolü gibi eylemler için de kullandıkları belirlenmiştir.

*Corresponding Author: ekaratas@ankara.edu.tr

${ }^{a}$ Asst. Prof. Dr., Ankara University, Ankara/Turkey, http://orcid.org/0000-0003-4336-6232 


\section{Introduction}

It is a common fact that individuals' having smartphones across the globe has become widespread. According to 2017 data, $75 \%$ of American adults and $92 \%$ of the American young adults aged 18-29 are known to have a smartphone (Olmstead, 2017). In 2017, the Internet usage was revealed to be $66.8 \%$ by individuals in the 16-74 age group (TÜIK, 2017). For university students who are a part of the society, smartphones (Hawi \& Samaha, 2016; Judd, 2014) have become an inseparable part of them. According to the data from the 2014 Educause Analysis and Research Center, 86\% of undergraduate students (Dahlstrom \& Bichsel, 2014) and 15\% of the young American adults, between 18-29 years, have a smartphone (Smith, et al., 2015). Students use smartphones not only in spare time activities but also in in-class activities (Felisoni \& Godoi, 2018) and this usage has become a natural part of the process (Kim, et al., 2017). In Turkey, in 1994, the number of mobile phone subscribers was 81.276, and according to the June 2017 data, this number reached 76.616.147. Again, the number of the Internet subscribers according to the same data is 66.436.443. (Since Turkish Statistics Institute or other researches did not have detailed information about mobile phone usage, no data was presented on a country basis.)

In order to understand why students' use smartphones, it is useful to look first at, why smartphones have become a part of everyday life of all the individuals. Smartphones are handheld devices, which provide access to the Internet, and facilitate the daily lives and professional activities of individuals (Anshari, Almunawar, Shahrill, Wicaksono, \& Huda, 2017). The fact that smart phones have the capacity to store thousands of things such as photos, video, sound, applications, games, etc., (Hawi \& Samaha, 2016), enhances the charm of these devices. The reasons for the use of smartphones in daily life vary: Communication, productivity, entertainment, social networks, games (Kwon, Lee, Won, Park, Min, Hahn, et al. 2013), access to information via the Internet, finding addresses, reading news online or taking photos (Chen \& Yan, 2016) are among a few of the reasons. Moreover, today, a wide range of applications suitable for all ages, preferences and intentions of use are offered to users in application markets (Hawi \& Samaha, 2016).

When we look at the students' smartphone usage; they benefit from smartphones as a learning assistant for many reasons, including ease of use, portability, comprehensive learning experience, multi-resource provisioning and multi-tasking and being eco-friendliness (Anshari, Almunawar, Shahrill, Wicaksono, \& Huda, 2017). There are two contrasting opinions on the use of smart mobile phones in educational environments of students. The first focuses on the negative aspects of its use, while the other draws attention to the positive aspects. The problem of this research is to investigate the positive effects of smartphone use during the training process.

\section{Smartphone Usage in Educational Environments}

According to Bradford Networks 2013 study, $89 \%$ of the colleges and universities in the USA and the UK, and $44 \%$ of elementary and high schools allow them to bring their own devices to school and use them (O'Bannon, Dunn, \& Park, 2017). Some teachers believe that they should allow the use of smartphones in their classrooms (Ruggiero \& Mong, 2015). In traditional university teaching, especially in large classrooms, the instructor teaches, and the student takes individual notes about this course. Nowadays, traditionally called face-to-face education has had to turn its face into many resources offered online. Student-centered practices such as flipped classes and collaborative learning lead to the development of cooperative note taking strategies (Kuznekoff, Munz, \& Titsworth, 2015). Today, instructors and teachers make choices, through a mass of online resources and share that they find useful with their students (Anshari, et al., 2017). In addition, instructors and teachers encourage and assist students to use the online resources correctly at least that is the way it should be. Teens prefer smartphones to other devices in accessing the Internet (García-Ormaechea, 2014). According to the study of Advanced Placement (AP) and National Writing Project (NWP), 73\% of the teachers expressed that they use smartphones to complete students' homework, $79 \%$ to access students' homework and $76 \%$ expressed the usage of a smartphone to deliver the students' homework online (Purcell, Heaps, Buchanan, \& Friedrich, 2013).

Many students use the camera of smartphones to receive lecture notes or other notes given by instructors (Anshari, et al., 2017). In the study of Junco and Cotton (2011), it is understood that $93 \%$ of students are actively chatting on smartphones while doing homework. According to the study with university students by Tindell and Bohlander (2012), 90\% of the students are messaging during class presentations. Yıldırım, Yaşar, and Murat (2016) conducted a study with 30 students to investigate the effects of the use of smartphones in educational environments. They found that secondary school students use their smartphones to communicate with their families, to take photos of lecture notes, and to deal with their time when they are bored. In addition to these 
intended uses, they have obtained the result that high school students use their smartphones in the educational environments to make repetitions, to complete their homework and to cheat. Gökdaş, Torun, and Bağrıaçı's (2014) research on student candidates with 656 education faculty students to determine their educational use of mobile phones and their views on mobile learning, provided that mobile phones were used primarily as communication tools, taking photos, and time planning.

If the reasons for smartphone usage are to be listed in educational environments:

- online chat, blogging, tweeting, or enhancing the interaction between student and instructor through other social platforms, providing interaction and sharing between peer groups, collaboration, providing student centered learning and differentiation of teaching (Alarabiat \& Al-Mohammad, 2015; Anshari, et al., 2017, Corbeil \& Valdes-Corbeil, 2007; Echeverria, et al., 2011; Gökdaş, Torun, \& Bağrıç̧1k, 2014; Kukulska-Hulme, 2007);

- visualizations of different subjects, analysis of these images, creating electronic reports, blogging, wiki, digital photography and sharing, providing information communication with tools such as digital stories, taking advantage of the camera (Gökdaş, Torun, \& Bağrıçık, 2014; Nakamura, Hanamitsu, \& Minamizawa, 2015; O'Bannon, Dunn, \& Park, 2017; Yıldırım, Yaşar, \& Murat, 2016);

- $\quad$ article readings, sharing attractive articles with each student or silent e-group discussions (Alarabiat \& Al-Mohammad, 2015; Au, Lam, \& Chan, 2015);

- $\quad$ create content, access content, find additional information, search for specific information (Alarabiat \& Al-Mohammad, 2015; Bull \& Thompson, 2004; Echeverria, et al., 2011; Hartnell-Young \& Vetere, 2008);

- $\quad$ evaluation and reflection (Markett, Sanchez, Weber, \& Tangney, 2006; Thomas, O’Bannon, \& Britt, 2014);

- management associated with the course, entertainment, such as playing games, listening to music, watching videos (Alarabiat \& Al-Mohammad, 2015),

- $\quad$ translation, spelling control, word search and dictionary access (Al Hamdani, 2014);

- document sharing, syncing, storing and restoring documents shared by academics and students (Johnston, 2016)

are seen. Wang et al. (2009) classified the effect of smartphone usage in the classroom on the human behaviors as; performance expectation (the perceived benefit of mobile learning), effort expectation (the easiness of smartphone usage for the perceived learning by the users), social effect (belief towards how the other people adopt to mobile learning), perceived entertainment (smartphone usage entertainment except form learning process) and selfmanagement of learning (the expression of how an individual her/himself during the connection process to an authentic learning environment).

An indication of the widespread use of smartphones with so many and various uses is also revealed by the work of Smith et al. (2015). According to this study, 99\% of the undergraduate students who declared that they own a smartphone stated that they have used their mobile phones at least once during the last hour of their courses. However, when the literature is examined, as mentioned above, there are two contrasting opinions that look positively and negatively in the use of smartphones in educational environments, but most of the research has been observed to focus on the negative opinion. There are two arguments in the negative facing studies: The first is the addiction caused by excessive use, and the other is multi-tasking caused by excessive use, which is allowed by smartphones to do multiple jobs simultaneously, that causes division and distraction. As a result of the division and distraction, the course process has a breakdown of the natural flow. The outcome of both negative situations is a decrease in the success of the course. Brief explanations of some of the studies that have revealed these situations are mentioned below.

The definitions of internet addiction, mobile addiction and smartphone addiction differ according to the literature (Lee, et al., 2015). Hwang, Son, \& Choi (2011), express the level of dependence on the smartphone, as being addicted to the smartphone, the fact of obsessive usage and putting daily life into trouble. In the definition of Yoon et al. (2011), it is pointed out, that the lack of mobile phone leads to irritability and anxiety disorder and 
the inability to concentrate on the work. Felisoni and Godoi (2018) think that the negative effect of the usage of smartphones or other technologies on academic performance could be due to their "excessive" use. Excessive use of smartphones or other technologies can cause the instructors to be distracted and a negative reflection on the quality of the lesson and other class activities. It is claimed that students who use this kind of technology too heavily, can "poke" other students in the class, with application control, instant messaging, etc. They also think that some mobile phone applications may be more harmful than others may. Tesch, Coelho, and Drozdenko (2011) point out that not only the use of personal technology, but also the use of technology by others (phone ringing, etc.) will distract attention. According to the researches if there is no specific usage policy or proper supervision, students use their mobile phones more often in appropriate conditions such as large/crowded classrooms or if the teacher does not move in the classroom (Mitchell, Finkelhor, \& Wolak, 2005).

In the study of Lee, Cho, Kim, and Noh (2015), they attempted to understand the difference between selfcontrolled learning and learning flow, focused on university students' addiction on smartphones and based on the level of smartphone addiction. The learning flow is described as the fully concentration and entertainment of a person while participating in an activity (Csikszentmihalyi, 1990) and the person's showing emotional or behavioral effort (Marks, 2000). With the pleasure of the flow, the student's satisfaction level, learning quality and learning results are increasing (Kim, Tak, \& Lee, 2010). In the study conducted with 210 students, it was seen that the self-controlled learning of the students with high level of dependency was low, similar to the low flow during the study. In the study of Lee, et al. (2015), it was observed that smartphone addicted students were regularly interrupted by different applications on the phones while working, and it was seen that they had no control over their plans for learning with the mobile phone. However, it was also observed that those who use smartphones in an excessive way have social problems in their daily lives.

The 1839 American university students who participated in the study of Junco and Cotten (2011), it was observed that the average academic performance of students who spend, on a daily basis, quite a long time with smartphones are declining in the opposite proportion. In Duncan, Hoekstra and Wilcox's (2012) study with university students, it was seen that there is a reverse relationship between the use of mobile phone in class and the final grades.

In the study of Rosen, Carrier, \& Cheever (2013), it was seen that 263 American students between 11-25 years, using Facebook and messaging while working, had lower average academic achievement scores than those who did not. In the study of Felisoni and Godoi (2018), they used two applications called "Moment" and "App Usage Tracker" to understand the amount of time students spend on their mobile phones. When the academic achievements of 250 students enrolled in the business school in Brazil were compared with the time they spent using a smartphone, it was observed that in response to every 100 minutes, the school success decreased by 6.3 degrees. Moreover, this ratio is doubled when considering the use during the class.

In fact, there is also an emotional aspect of the negative aspect on the usage of smartphones in educational environments. In the study conducted by Abramova, Baumann, Krasnov, and Lessmann (2017) with 60 university students, the "phub" act in academic environments was discussed. The "Phub" action is described in the Cambridge Dictionary as ignoring the person you are together and dealing with your own mobile phone instead. The MacMillan Dictionary, on the other hand, characterizes this action as a rude behavior. In their work with observation, survey and focus group interviews, Abramova et al. (2017) showed that students' mobile phone usage steals significantly time of the course, and often underestimate the impact of this behavior on the learning process. This study shows that the number of times a student looks at the smartphone during the course, is negatively correlated with visual attention, and that the total duration of smartphone usage worsens auditory attention.

If it comes to the multitasking feature of smartphones, Chen and Yan (2016) describe this feature with an example. When individuals read an article, regularly and continuously checking their e-mails is defined as multitasking, while reading articles with the aim of learning on mobile phones is referred to as mobile learning. Although multi-tasking is not a new phenomenon, there is an increase in the number and type of digital activities that people can perform simultaneously. The accessibility of new technologies, perceived ease of use, and a wide range of events makes it easy for adult and young learners to connect to non-tasking behaviors in teaching contexts (Wood, et al., 2012).

Wood, et al., (2012), describes multitasking as doing more than one job at the same time. Junco (2012) defines this as "transition between non-well-structured and non-sequential tasks performed during learning situations and split attention". From this definition, Wood et al. (2012) state that processing of the information will take more 610 
time and Chen and Yan (2016) however state, that some information may be lost during the inter-stimulus transition process. Multitasking with technology can affect efficiency and productivity in the academic context negatively (Karpinski, Kirschner, Ozer, Mellott, \& Ochwo, 2013). Chen and Yan (2016) examined 132 published studies on the subject area between the years 1999-2014 and found that the use of mobile phones lead to multitasking and distraction; and classified them under three titles: the sources of the distraction (phone ringing, social applications and messaging), the objectives of the distraction (reading and participation), the subject of the distraction (personality, gender and culture).

Most of the research reveals that mobile phone usage in the classroom causes distraction (Baker, Lusk, \& Neuhauser, 2012; Dietz \& Henrich, 2014; Hawi \& Samaha, 2016; Kim, et al. 2017; Lenhart, Ling, Campbell, \& Purcell, 2010; McCoy, 2013; Thomas et al., 2014;), and that messaging in the classroom reduces student performance (Dietz \& Henrich, 2014; Rosen, Lim, Carrier, \& Cheever, 2011). Kim, Jung, Jung, Ko, and Lee (2017), in order to explore the usage of smartphones by college students outside the classroom, out of duty, multitasking features, had made pre-interviews with 47 instructors and 283 students and they provided a software called Let's FOCUS developed by them, to volunteers in one of the Korean universities to try. 370 students in 233 classes used this downloaded application for 9335 hours. Kim et al. (2017) and Hawi and Samaha (2016) state that multitasking requires cognitive processing, which may cause a cognitive overload. For example, a student who replies to a message from his friend will stop listening to the instructor for a while. Ophir, Nats, and Wagner (2009) reveal that intensive multi-tasks are less successful in filtering irrelevant information and are slower in transitions between tasks, according to light multi-tasks. According to Just, Carpenter, Keller, Emery, Zajac, \& Thulborn (2001), students who use smartphones, accepting interruptions with notifications during learning and interrupt their learning processes and switching to non-academic tasks, will have losses in their learning (Hawi \& Samaha 2016). The presence of tools that make learning efficient on smartphones, contrary to the belief that it is used in the reinforcement of new learned and in the interacting of students and instructors, causes a split in the classroom or in any other environment related to study (Felisoni \& Godoi, 2018).

Lepp, Barkley, and Karpinski (2014) conducted extensive studies with 536 American university students, showing that messaging has an inverse relationship with the average academic success, also having a positive relationship with anxiety, and it has revealed that academic success has a positive relationship with satisfaction from life and that is has a relationship with anxiety in the opposite direction. According to Wood, Zivcakova, Gentile, Archer, De Pasquale, and Nosko (2012), multitasking with the technologies of e-mail, messaging, Facebook, etc., has a negative relationship with effective learning, and turns out in low-test results. Instant messaging faces us as a serious distraction (Junco \& Cotten, 2011).

On the one hand, in the classroom or out-of-class learning situations, the negative aspects of smartphone usage are noted, it is also obvious that this negativity cannot be avoided in the opposite direction. For example, although Facebook's main purpose is socializing and entertainment, an increasing number of students are known to be using Facebook for academic purposes and set up working groups and meetings (Alarabiat \& Al-Mohammad, 2015; Johnston, Chen, \& Hauman, 2013). In 2011, the number of undergraduate students who say they own smartphones has increased from 55\% to $62 \%$ in 2012 . The smartphone usage rate for academic purposes increased from $37 \%$ in 2011 to up to twice in 2012 (67\%) (Dahlstrom, 2012).

The fact that the majority of academics have become active Youtube users (Roodt, de Villiers, Johnston, Ophoff, \& Peier, 2014) and the effectiveness of wikis on the group work of students (Burton, 2015) cannot be ignored. Kuznekoff, Munz, and Titsworth (2015) point out that although allowing students to communicate and tweet during class makes learning less successful, the correct integration of these devices will help the students to learn. The multitasking capabilities of smartphones can be used for educational purposes like, in-class learning, out of class work, in individual or group work and for homework (Jacobsen \& Forste, 2011; Junco, 2012). Bollliger and Shepherd (2016) argue that devices that make it possible to connect to the Internet are contributing to learning via instant and direct experience and it means that the devices that make it possible to connect to the Internet should be balanced by taking the positive and negative aspects into consideration.

Thomas and Orthober (2011) state that messaging provides communication, interaction, and collaboration between teacher, student, and the content. In addition, Ruggiero and Mong (2015) suggest that the use of mobile devices in the classroom will have a positive unexpected effect, such as the ability to get rid of paper and turn into "green" classes. Johnston (2016) suggests that it is impossible for any academician or student not to want to use mobile devices in the classroom. There is no way, for both academics and students, to lose notes they took with 
these devices, there's also no loss of meaning due to bad handwriting, conversion to paper-free "green" classes can occur, all documents can be shared, and are always accessible. Moreover, many people generate new information from the information they obtain from the Internet using their smartphones (Anshari, Almunawar, Shahrill, Wicaksono, \& Huda, 2017). Chen and Tzeng (2010) revealed that students who frequently search for information on the Internet are more successful than students who search less.

According to the study conducted by Kuznekoff, Munz, and Titsworth (2015) on 8 groups, according to control and experimental groups, students who do not tweet or respond to irrelevant messages have obtained a higher grade by $10-17 \%$, it has been observed that they received a higher score for the recall of information (70\%) and for taking notes $(50 \%)$ compared to the students who tweet or respond to irrelevant messages. Sending/receiving irrelevant messages to the class content has caused adverse effects on learning and taking notes, while sending a related message has not a significant negative impact. Judd (2014) reveals that the use of Facebook provides significant contributions to the multi-tasking skills in students ' work.

Felisoni and Godoi (2018) based on past studies; think that there may be a relationship between time management skills and smartphone usage, and that these variables will adjust focus and attention. Again, Felisoni and Godoi (2018) in literature studies, bring a different perspective on how smartphone usage leads to low academic skills, perhaps it also means that individuals with low academic skills need to be questioned about their frequent smartphone usage. Chen and Yan (2016) point out that it is important to look at the impact of different tasks, while investigating the impact of multiple tasks on learning. This is explained by auditory and visual tasks. When you take a note of a verbal-listened course, listening to voice messages can lead to distraction, and it may be easier to look at an image sent by your friend while taking a note of the verbal-listened course.

\section{Aim of the research}

Chen and Yan (2016) pointed out that the reason for the search of literature on this field is that smartphones becoming indispensable in everyday life, and educational environments, the use of the multi-tasking feature of smartphones in the learning process, the complexity of this process and the urgency of addressing this situation. For the same reasons, post-graduate students' views on this situation, has been a source of motivation for this study. The aim of this research is to seek answers to the question what the positive effects of the use of smartphones in the education processes of graduate students are.

\section{Method}

The research design, study group, and data collection tool are included in this section.

\section{Research Design}

In this study, as Cresswell (2003) stated, the case study was adopted from qualitative research methods in order to trying to investigate a situation in depth, in a particular period of time. In this study, the positive effects of smartphone usage were tried to be handled with a holistic approach and how the students were affected by this situation was tried to be revealed. In this study, a single case was addressed and included in the Type 1 category of the Case Study of Yin (2013).

\section{Study Group}

In order to reach the study group, at the Institute of Educational Sciences in one of the most established universities in Ankara, the faculty members who teach masters and doctorate courses in 10 different branches were requested to send invitations to students by e-mail who are attending classes and would like to participate voluntarily in this study. 29 students responded to the study.

Age distributions of participants are presented in Table 1.

Table 1. Age Distribution of Participants

\begin{tabular}{ll} 
Age & f \\
$21-24$ & 19 \\
$25-28$ & 6 \\
$>28$ & 4 \\
Total & 29 \\
\hline
\end{tabular}


When Table 1 is examined, it is seen that the majority of the participants $(n=19)$ are in the age range of 21 24 years. There are 6 participants in the 25-28 age range, and 4 in the age group of 28 and above. Considering that the participants are graduate students, the majority of participants are expected to be between 21-24 years of age, since the rate of starting a master's degree is higher immediately after the undergraduate education. 20 of the participants are female and 9 are male.

he program distributions in which the participants are registered are presented in Table 2.

Table 2. Distributions of programs where participants are registered

\begin{tabular}{ll}
\hline Program & f \\
Social Studies Education & 9 \\
Science Education & 4 \\
Classroom Training & 4 \\
Mathematics Education & 3 \\
Chemistry Education & 3 \\
Physics Education & 2 \\
Computer and Instructional Technology Education & 2 \\
Biology Education & 2 \\
Total & 29
\end{tabular}

When Table 2 is examined, it is observed that participants are from following departments; Social Studies Education $(n=9)$, Science Education $(n=4)$, Classroom Education $(n=4)$, Mathematics Education $(n=3)$, Chemistry Education $(n=3)$, Physics Education $(n=2)$, Computer and Instructional Technology Education $(n=$ 2), Biology Education $(n=2) .15$ of the 29 participants stated that they were working full time, one was working part time, and 12 were not working.

Participants' smartphone brand distributions are presented in Table 3.

Table 3. Participants' Smarphone Brand Distributions

$\begin{array}{ll}\text { Brand } & \text { f } \\ \text { Iphone } & 12^{*} \\ \text { Samsung } & 8 \\ \text { LG } & 5^{*} \\ \text { Sony } & 2 \\ \text { Asus } & 1 \\ \text { Huawei } & 1 \\ \text { Xiaomi } & 1 \\ \text { Total } & 30\end{array}$

* One person has two phones

When the Table 3 is examined, it is observed that participants use the following smartphones respectively, Iphone $(n=12)$, Samsung $(n=8), \operatorname{LG}(n=5)$, Sony $(n=2)$, Asus $(n=1)$, Huawei $(n=1)$ and Xiaomi $(n=1)$. One participant reported that $\mathrm{s} / \mathrm{he}$ had 2 phones.

Participants' daily smartphone usage time distributions are presented in Table 4.

Table 4. Participants' Smartphone Usage Time Distributions

\begin{tabular}{ll} 
Time/Duration & f \\
$1-2$ hours & 4 \\
$2-4$ hours & 8 \\
$4-6$ hours & 7 \\
\hline
\end{tabular}




\begin{tabular}{ll}
\hline $6-8$ hours & 6 \\
Continuous use & 4 \\
Total & 29 \\
\hline
\end{tabular}

When the Table 4 is examined, it is observed that 4 of the participants use their smartphones less than two hours, 8 of them use their smartphones about/between 2-4 hours, 7 of the participants use them between 4-6 hours and 4 of them use their smartphone more than 6 hours on a daily basis. The results of Aljomaa, Al Qudah, Albursan, Bakhiet and Abduljabbar's (2016) research, also support this study. In the study of Aljomaa et al., they investigated 416 university students to determine their smartphone addiction and found that 37 of the students used their phones less than 2 hours a day, 110 students used their phones 2-4 hours a day, and 269 students more than 4 hours a day

\section{Data Collection Tool}

The study aims to reach graduate students, and the instructors, who teach this target audience, were asked to reach to their students. An opinion form was prepared to obtain the views of the students who agreed to participate in the research. While the opinion form was being prepared, similar studies were carried out in the field (Anshari, et al., 2017; Bolkan and Griffin, 2017; Kim, et al., 2017; Muñoz and García, 2016; Wood, et al.) The questions include issues as the rationale for students to use smart phones for educational purposes, their impact on their academic performance, and their ability to feel safe. In terms of the scope and expression of the opinion form, opinions from two experts in the field of Computer and Instructional Technology Education were taken. The finalized opinion form according to the experts' opinions consists of 7 questions for determining the general characteristics of the participants and 7 questions for obtaining the opinions of the students.

\section{Findings}

Findings for the purpose of the research are presented in this section.

Participants were asked, "Do you check or use your smartphones during your course in your Master's courses? What is the reason for your behavior?" 3 (1 female, 2 male) of the 29 participants, answered no. The answers of the participants who answered yes on the reasons for usage are presented in Table 5.

Table 5. Participants' Reasons for Using Smartphones during Class

\begin{tabular}{ll} 
Justification for use & $\mathbf{f}$ \\
I check incoming notifications. & 10 \\
I check the clock or the calendar. & 8 \\
I investigate a subject or term that is referred to in the course. & 8 \\
I make an emergency call. & 5 \\
I use it because of curiosity/habit/addiction. & 5 \\
I use it for personal purposes. & 4 \\
I use it when I'm bored. & 2 \\
I use it for business. & 2 \\
Table 5 Continuation & 1 \\
\hline I take notes. & 1 \\
I don't use it in class. & 1 \\
I use it when I think I won't attract attention. & 47 \\
Total & \\
\hline
\end{tabular}

When the Table 5 is examined it is observed, that the participants use their mobile phones, in order to control incoming notifications $(n=10)$, check the clock or calendar $(n=8)$, investigate a subject or term that is referred to in the course $(n=8)$, make an emergency call $(n=5)$, due curiosity/habit/addiction $(n=5)$ or for personal purposes $(n=4)$. Two of the participants clearly stated that they looked at their smartphones when they were bored, incoming notification control, or the control of the clock could be due to being bored. Bolkan and Griffin (2017), referring 
to Keller's 1987 opinion of motive, that as long as we do not kill the students' interests, we prevent them from getting bored, drew attention to the fact that this is still a problem today confronting the educators. Researchers such as Pekrun, Goetz, Daniels, and Stupinsky (2010), Nett, Goetz, and Hall (2011), Mann and Robinson (2009) and Goetz and Hall (2014) all point out that the majority of the students are bored in most of the courses. Researchers, such as Emanuel (2013) and McCoy (2013), also point out that, when students are bored in the class, they hide behind their mobile phones. A participant also stated that he used the smartphone when he thought he would not be noticed. In a study by Mitchell, Finkelhor, and Wolak (2005), in cases where the teacher does not notice the use of mobile phones, they observed that students use their mobile phone more often. Although the target group of Yıldırım, et al.'s (2016) study is secondary and high school, the findings are consistent with this research. In addition, Gökdaş et al.'s (2014) research result (prospective teachers use their smartphone for time planning) supports this research.

The answers of the participants to the questions "How does dealing with your smartphones affect your performance? Does checking your smartphones cause you to quickly relax or divide your course concentration?" are presented in Table 6.

Table 6. The Impact of Smartphone Usage during the Courses on the Performances of Participants in the Courses

$\begin{array}{ll}\text { Effect on Performance } & \text { f } \\ \text { It has no effect on my performance. } & 9 \\ \text { I relax. } & 7 \\ \text { It rarely affects my performance. } & 5 \\ \text { When I stay away from the phone, it's on my mind. } & 4 \\ \text { It's negatively affecting my performance. } & 4 \\ \text { It's increasing my motivation. } & 3 \\ \text { Total } & 32\end{array}$

When Table 6 is examined, most of the participants stated that using a smartphone in the course does not affect their performance $(n=9)$ or stated that they were relaxed $(n=7)$. In addition, participants stated that, the use of smartphones rarely affects their performance $(n=5)$, when they have no access to their phones, they have it in their mind $(n=4)$, it negatively affects their performance $(n=4)$ and it increases their motivation $(n=3)$. Looking at the literature, in contrast to this study, as pointed out earlier in most researches (Dietz \& Henrich, 2014; Rosen, Lim, Carrier, \& Cheever, 2011), it has been concluded that smartphone usage in class has lowered student performance. The contradiction of the findings in this research with the literature could be because the participants are graduate students; so their awareness levels are high and therefore may not adversely affect their performance. From another point of view, this study is based on the statements of graduate students, but the participants' real-life behaviors and statements can be different, as seen in Duncan, Hoekstra, and Wilcox's (2012) researches.

The answers of the participants to the question "Does it make you feel safe to have your smartphone on your side during the course? Explain why." are presented in Table 7.

Table 7. The Impact of Participants' Smartphone Usage during the Course on the Sense of Trust

\begin{tabular}{ll} 
The effect on the sense of trust & f \\
I feel safe. & 23 \\
It does not provide a sense of trust. & 5 \\
I do not use it in class. & 1 \\
Total & $\mathbf{2 9}$ \\
\hline
\end{tabular}

When Table 7 is examined, a large part of the participants stated that using smartphones during the course makes them feel safe $(n=23) .5$ participants stated that using a smartphone does not provide any sense of trust while a participant stated s/he did use a smartphone during the course. Looking at the literature, Johnston (2016) conducted a study through observation and interaction on the use, impact and unintended consequences of webassisted mobile devices on graduate students in Africa (South Africa) and Europe (Germany). Contrary to the research results that mobile devices do not adversely affect the classroom, it has revealed that students are more connected and more comfortable when they are granted access to mobile devices. 
The answers of the participants to the question "Can you explain how you use your smartphones for educational purposes in your master classes?" are presented in Table 8.

Table 8. Participants' Usage of Smartphones for Educational Purposes during the Courses

$\begin{array}{ll}\text { Usage for educational purposes } & \text { f } \\ \text { I investigate a subject or term that is referred to in the course. } & 21 \\ \text { I send and receive e-mails. } & 6 \\ \text { I follow the course material. } & 5 \\ \text { I examine thesis and articles. } & 5 \\ \text { I take notes. } & 4 \\ \text { I do voice recording. } & 2 \\ \text { I use it for translation. } & 1 \\ \text { I take a photo of the board. } & 1 \\ \text { Total } & 45\end{array}$

When the Table 8 is examined, a very large part of the participants stated that they used their smartphones to investigate a subject or term that was referred to in the course $(n=21)$. Other uses include sending and receiving email $(n=6)$, following course materials $(n=5)$, examining thesis-articles $(n=5)$, taking notes $(n=4)$, voice recording $(n=2)$, use for translation $(n=1)$ and take a photograph of the board $(n=1)$. Researches in literature of smartphone usage in educational environments and the findings of this research are seem to be consistent (Alarabiat \& AlMohammad, 2015; Al Hamdani, 2014; Anshari, et al., 2017; Au, Lam, \& Chan, 2015; Corbeil \& Valdes-Corbeil, 2007; Echeverri, 2011; Kukulska-Hulme, 2007; Nakamura, Hanamitsu, \& Minamizawa, 2015; O'Bannon, Dunn ve Park, 2017).

The answers of participants to the question "Would you describe what features of your smartphone you use in the course process during your master's degree education?" are presented in Table 9.

Table 9. Participants' use of Different Features of Their Smartphones during the Courses

\begin{tabular}{ll} 
Smartphone Features & f \\
I make searches on the Internet. & 19 \\
I send and receive e-mails. & 8 \\
I take notes. & 7 \\
I use it for instant communication (WhatsApp). & 6 \\
I take photos/videos. & 6 \\
I use it for storage (access to saved files). & 6 \\
I make voice recording. & 3 \\
Table 9 Continuation & 3 \\
\hline I use it as a calendar/reminder/things to do list. & 3 \\
I check the clock. & 2 \\
I look up in the dictionary. & 2 \\
Total & 63 \\
\hline
\end{tabular}

When the Table 9 is examined, participants often use features like, use the Internet $(n=19)$ being in the first place, e-mail $(n=8)$, taking notes $(n=7)$, instant communication $(n=6)$, taking photos/videos $(n=6)$, as storage $(n=6)$. Other than these, they also benefit from features such as voice recording $(n=3)$, calendar/reminder $(n=3)$, clock $(n=3)$ and dictionary $(n=2)$. When the literature is examined, it is seen that just as it is in this research the most preferred feature in terms of the usage of smartphones during courses is the Internet access, followed by e-mail sending/receiving, instant messaging, taking notes and taking photos/videos (Alarabiat \& Al-Mohammad, 2015; Bull \& Thompson, 2004; Echeverria, et al., 2011; Hartnell-Young \& Vetere, 2008). Answers to the question "Do you use your smartphones in conjunction with your master's courses after the course? If your answer is yes, for 616 
what purposes do you use it. Can you explain the effects of this use in terms of time management?" 17 out of 29 participants (13 female, 4 male) stated using the smartphone in conjunction with the course outside the classroom saves time and increases their productivity. The answers of participants to the out-of-class smartphone usage are presented in Table 10.

Table 10. Participants' course related usage of smartphones after the course

\begin{tabular}{ll} 
Course related usage outside of course & f \\
I use it to access online resources. & 12 \\
I use it for instant communication (Whatsapp) with my classmates. & 5 \\
I search on the Internet (thesis search, Mendeley, Google Scholar). & 4 \\
I send and receive e-mail. & 4 \\
I listen to voice recordings (previously recorded voice). & 2 \\
I make a wireless network sharing. & 2 \\
I take photos/videos. & 1 \\
Total & $\mathbf{3 0}$ \\
\hline
\end{tabular}

When Table 10 is examined, the main reasons for using smartphones related to the course after the course are observed as; access to online resources $(n=12)$, instant communication with the course mates $(n=5)$, searching the internet $(n=4)$, e-mail sending-receiving $(n=4)$. Other than that, participants expressed their intentions as listening to voice recording $(n=2)$, wireless network sharing $(n=2)$, taking photos/videos. The study of Anshari, Almunawar, Shahrill, Wicaksono, and Huda (2017) also supports this study: Students, who participate in the research use their smartphones to access information and course materials that can be accessed via the Internet, interact with teachers outside the classroom, management of group homework.

In Table 11, participants' answers to the question "As a student, what do you think about faculty members, who check or use their smartphones during class in your master's courses?" are presented.

Table 11. Participants Point of View on Instructors' Usage of Smartphones during the Course

$\begin{array}{ll}\text { Thoughts on use through the instructor } & \text { f } \\ \text { I don't feel uncomfortable if they use it. } & 14 \\ \text { They do not use it, except in an emergency. } & 8 \\ \text { I'm uncomfortable with non-purpose use. } & 4 \\ \text { As long as there's no negative impact on the course process, there is no problem. } & 3 \\ \text { Total } & \mathbf{2 9}\end{array}$

When Table 11 is examined it is seen that the participants stated their point of view on the time faculty members used their smartphones during the course as follows; I don't feel uncomfortable if they use it $(n=14)$, they do not use it, except in an emergency $(n=8)$, I feel uncomfortable with non-purpose use $(n=4)$, as long as there's no negative impact on the course process, there is no problem $(n=3)$. When the literature is examined, there are very few studies addressing students ' opinions on the use of smartphones by faculty members. Nevertheless, it is possible to come across studies that demonstrate the usage of smartphones during the course provides interaction, communication and cooperation between teachers, students and content (Johnston 2016; Thomas and Orthober, 2011).

\section{Limitations of the Study}

In this research, the answers to the questions asked to the graduate students are limited to the statements of the persons because they are in the form of self-evaluation. They may not be able to calculate how busy they are with their smartphone on a daily basis and may not be aware of their routine behavior in their own nature. Furthermore, when "smartphone use" is mentioned, behaviors that emerge in the minds of participants may differ. In addition, as the literature often emphasizes and the individuals in the society consider it as addictive, the usage of smartphones during the course is perceived as a negative behavior. This perception may have been reflected in the response of the students considering using time and objectives as unimportant. Similar situations were seen in the 
literature. Duncan, Hoextras, and Wilcox (2012) have actually observed that the students' smartphone usage time in real-time class events is 21 times per course, although students reported their smartphone usage time with an average of 3 times per course.

The generalization of the results of this study will not be healthy in terms of the study group. As stated above, this research is limited to students enrolled in only one educational science institute, who are studying at the same time. Although students from different branches have been included in the study, it is possible to achieve different endpoints when the study is repeated with students enrolled in different institutes.

\section{Results}

If students' opinions are to be summarized from the findings, the graduate students participating in this research used for searching the subject or term which is referred to in the course, academic research, following course materials, taking notes with photo or voice note feature, communicating with peers and teaching staff, they use their smartphones as well as for actions that are not relevant to the course, such as checking incoming notifications or the clock, because they are bored during the lesson. Despite the existence of similar studies in the literature and its limitations, this study is thought to contribute to the literature, especially in the context of graduate students and reflecting Turkish culture. Although it is strongly argued that the use of smartphones during course and extracurricular activities related to the course may cause divisions, the use of optimum duration and optimum tools provide significant contributions to the learning process and duration. Anshari et al. (2017) advocate the opinion that the distractions of these devices in the classroom environment will be reduced if the instructors create appropriate interaction environments and design activities that will appeal to students in accordance with the use of smartphones in the class. Felisoni and Godoi (2018) also underline that appropriate academic environments must be designed so that smartphones can become a powerful learning support tool, and that new studies should be planned in this direction. Here, the level of consciousness and the influence of cultures cannot be denied. Therefore, the consciousness level related to the learning processes will reveal more positive results in studies with graduate students. The greatest challenge for the 21 st century lectures is to get students attention and make sure they get attached to the class, due the extreme simplicity of connecting with the outside world with mobile devices. The presence of students who are physically present in the classroom but who are mentally connected to mobile devices with materials not related to the courses is inevitable (Kuznekoff, Munz, \& Titsworth, 2015). The best solution for these conditions would be to accept the students together with these devices and to adapt to the cultural change in order to integrate the positive aspects of these devices into education.

This research is not intended to be generalized as it is planned as a case study, therefore, quantitative studies can be planned for graduate students' use of smartphones in the education process. In addition, the participants' opinions on this research were examined based on their statements. Participants' statements could not always reveal the real situation, as it has been pointed out in the literature, sometimes because of the lack of awareness of the use of the smartphone, or of the feeling that the frequent use will not be tolerated by the society. For this reason, the planning of research on the natural processes in which behavior can be observed will contribute to the literature. Another study subject; a detailed examination of the opinions of the students regarding the usage of smartphones by lecturers during the course of education, especially during the training process will provide important findings. 


\section{Lisansüstü Eğitimde Akıllı Cep Telefonu Kullanımının Olumlu Etkileri Üzerine Bir Durum Çalışması}

Giriş

Dünya genelinde bireylerin akıllı cep telefonuna sahip olmasının yaygınlaştığı bir gerçektir. 2017 verilerine göre Amerikalı yetişkinlerin \%75'inin, 18-29 yaş arası genç yetişkinlerin ise \%92'sinin akıllı cep telefonu sahibi olduğu bilinmektedir (Olmstead, 2017). Akıllı cep telefonları, toplumun bir parçası olan üniversite öğrencilerinin de (Hawi ve Samaha, 2016; Judd, 2014) ayrılmaz bir parçası haline gelmiştir. 2014 EDUCAUSE Analiz ve Araştırma Merkezi'nin verilerine göre lisans öğrencilerinin \%86'sı (Dahlstrom ve Bichsel, 2014) 18-29 yaş arası genç yetişkin Amerikalı'nın \%15'i akıllı cep telefonuna (Smith, vd., 2015) sahiptir. Öğrenciler akıllı cep telefonlarını sadece boş zaman etkinliklerinde değil ders içi faaliyetlerde de sıklıkla kullanmaktadırlar (Felisoni ve Godoi, 2018) ve bu kullanım, sürecin doğal bir parçası halini almıștır (Kim, vd., 2017). Türkiye de ise, 1994 yılında cep telefonu abone sayısı 81.276 iken Haziran 2017 verilerine göre bu sayı 76.616.147'ye ulaşmıştır. Yine aynı verilere göre internet abone sayısı ise 66.436.443'tür. İnternet kullanımının 2017 yılında 16-74 yaş grubundaki bireylerde \%66,8 olduğu ortaya çıkmıştır (TÜiK, 2017). (TÜíK ya da başka bir araştırmada öğrencilerin cep telefonu kullanımına ilişsin detaylı bilgiye rastlanılmadığı için ülke bazında veriler sunulamamıştır).

Öğrencilerin neden akıllı cep telefonu kullandığının anlaşılması için öncelikle tüm bireylerde neden akıllı cep telefonlarının günlük yaşamın bir parçası haline geldiğine bakmakta fayda vardır. Akıllı cep telefonları; elde taşınan, internete bağlanmayı sağlayan ve bireylerin günlük yaşamlarını ve profesyonel etkinliklerini kolaylaştıran bir cihazdır (Anshari, Almunawar, Shahrill, Wicaksono, ve Huda, 2017). Akıllı cep telefonlarının fotoğraf, video, ses, uygulama, oyun gibi çok yer kaplayan binlerce uygulamayı/dosyayı saklama kapasitesine sahip olması (Hawi ve Samaha, 2016) bu cihazların cazibesini artırmaktadır. Akıllı cep telefonlarının günlük yaşamda kullanım nedenleri çeşitlilik göstermektedir: İletişim, üretkenlik, eğlence, sosyal ağlar, oyunlar (Kwon, Lee, Won, Park, Min, Hahn, vd. 2013), internet üzerinden bilgiye erişim, adres bulma, çevrimiçi haber okuma ya da fotoğraf çekme (Chen ve Yan, 2016), bu nedenlerden yalnızca bir kaçıdır. Üstelik bugün her yaşa, her tercihe ve her kullanım niyetine uygun çok çeşitli sayıda uygulama da uygulama marketlerinde kullanıcılara sunulmaktadır (Hawi ve Samaha, 2016).

Öğrenciler; kullanım kolaylığı, taşınabilirliği, kapsamlı öğrenme deneyimleri sağlaması, çoklu kaynak sunması, çoklu göreve imkan tanıması ve çevre dostu olma gibi birçok nedenden ötürü akıllı cep telefonlarından öğrenme yardımcısı olarak faydalanmaktadır (Anshari, Almunawar, Shahrill, Wicaksono, ve Huda, 2017). Öğrencilerin eğitim ortamlarında akıllı cep telefonu kullanımı üzerine iki zıt görüş bulunmaktadır. Birincisi, kullanımının olumsuz yönlerine odaklanırken diğeri ise olumlu yönlerine dikkat çekmektedir. Bu araștırmanın problemi de eğitim süreçlerinde akıllı cep telefonu kullanımının olumlu etkilerinin neler olduğunu araştırmaktır.

\section{Eğitim Ortamlarında Akılı Cep Telefonu Kullanımı}

Bradford Networks'ün 2013’te yaptığı araştırmaya göre, Amerika ve İngiltere'deki yüksekokul ve üniversitelerin \%89'unun, ilköğretim ve liselerin \%44'ünün, öğrencilerin kendi cihazlarını okula getirmelerine ve kullanmalarına izin verdikleri görülmektedir (O'Bannon, Dunn, ve Park, 2017). Bazı öğretmenler, sinıflarında akıllı cep telefonu kullanımına izin vermek gerektiğine inanmaktadır (Ruggiero ve Mong, 2015). Geleneksel üniversite öğretiminde hele ki geniş sınıflarda öğretim elemanı ders anlatır, öğrenci de bu derse ilişkin bireysel not tutar. Günümüzde geleneksel olarak adlandırılan yüz yüze eğitim yüzünü çevrimiçi sunulan birçok kaynağa çevirmek zorunda kalmıştır. Ters yüz sınıflar, işbirliğine dayalı öğrenme gibi öğrenci merkezli uygulamalar, işbirliğine dayalı not alma stratejilerinin de geliştirilmesine neden olmaktadır (Kuznekoff, Munz, ve Titsworth, 2015). Bugün öğretim elemanları ve öğretmenler, öğrencileri için yararlı buldukları yığınla sunulan çevrimiçi kaynak arasından seçimler yapıp öğrencileri ile paylaşmaktadır (Anshari, vd., 2017). Ayrıca öğretim elemanları ve öğretmenler, öğrencilerinin çevrimiçi kaynakları doğru kullanmaları için cesaretlendirmekte ve izlemektedirler, en azından böyle olması gerekmektedir. Gençler internete erişimde diğer cihazlara nazaran akıllı cep telefonlarını daha çok tercih etmektedir (García-Ormaechea, 2014). Advanced Placement (AP) ve National Writing Project'in (NWP) yaptığı araştırmaya göre öğretmenlerin \%73'ü öğrencilerin ödevlerini tamamlamak, \%79'u öğrencilerin ödevlere erişmek ve \%76's1 ise öğrencilerin ödevleri çevrimiçi teslim etmek amacıyla akıllı cep telefonu kullandığını dile getirmiş̧tir (Purcell, Heaps, Buchanan, ve Friedrich, 2013).

Birçok öğrenci, ders notlarını ya da öğretim elemanlarınca verilen diğer notları almak için akıllı cep telefonlarının kamerasını kullanmaktadır (Anshari, vd., 2017). Junco ve Cotton'ın (2011) çalışmasında, 
öğrencilerin \%93'ünün ödev yaparken aktif olarak akıllı cep telefonlarından sohbet ettiği anlaşılmaktadır. Tindell ve Bohlander'ın (2012) üniversite öğrencileri ile yaptıkları çalışmaya göre öğrencilerin \%90'ının sınıf sunumları esnasında mesajlaştıklarını göstermektedir. Yıldırım, Yaşar ve Murat'ın (2016) akıllı telefonlarının eğitim ortamlarında kullanımının etkilerinin incelenmesi amacıyla 30 öğrenci ile yapmış oldukları çalışmada ortaokul öğrencilerinin akıllı telefonlarını aileleriyle iletişim kurma, araştırma, ders notlarının fotoğrafını çekme ve sıkıldıkları zaman telefonları ile ilgilenme şeklinde belirlerken lise öğrencilerinin ise bu kullanım amaçlarına ek olarak konu tekrarı ve ödev yapma ile kopya çekmek amacıyla akıllı telefonlarını eğitim ortamında kullandıkları sonucunu elde etmiştir. Gökdaş, Torun ve Bağrıç̧ı'ın (2014) öğretmen adaylarının cep telefonlarını eğitsel amaçlı kullanımlarının ve mobil öğrenmeye ilişkin görüşlerinin tespit edilmesine yönelik olarak 656 eğitim fakültesi öğrencisi ile yapmış oldukları araşıırmalarında öğrencilerin cep telefonlarını öncelikle iletişim amaçlı olmak üzere, fotoğraf çekme ve zamanı planlama aracı olarak kullandıklarını sonucuna ulaşmıştır.

Eğitim ortamlarında akıllı cep telefonu kullanımının gerekçeleri:

- çevrimiçi sohbet, blog tutma, tweet atma ya da diğer sosyal platformlar yoluyla öğrenci-öğretim elemanı arasındaki etkileşimi arttırma, akran grupları arasında etkileşimi ve paylaşımı sağlama, işbirliği sağlama, öğrenci merkezli öğrenme sağlama ve öğretimi farklılaştırma (Alarabiat ve AlMohammad, 2015; Anshari, vd., 2017; Corbeil ve Valdes-Corbeil, 2007; Echeverria, vd., 2011; Gökdaş, Torun ve Bağrıçıı, 2014; Kukulska-Hulme, 2007);

- değişik konularda görsel sağlama, bu görsellerin analizi, elektronik rapor oluşturma, blog, wiki, dijital fotoğraf çekimi ve paylaşımı, dijital hikaye gibi araçlarla bilgi iletişimi sağlama, kameradan yararlanma (Gökdaş, Torun ve Bağrlaçık, 2014; Nakamura, Hanamitsuve Minamizawa, 2015; O'Bannon, Dunn ve Park, 2017; Yıldırım, Yaşar ve Murat, 2016);

- makale okumaları, ilgi çekici makaleleri öğrencilerin birbirleri ile paylaşmaları ya da sessiz e-grup tartışmaları (Alarabiat ve Al-Mohammad, 2015; Au, Lam ve Chan, 2015);

- $\quad$ içerik oluşturma, içeriğe erişim, ek bilgi bulma, belirli bilgi arama (Alarabiat ve Al-Mohammad, 2015; Bull ve Thompson, 2004; Echeverria, vd., 2011; Hartnell-Young ve Vetere, 2008);

- değerlendirme ve yansitma (Markett, Sanchez, Weber, ve Tangney, 2006; Thomas, O’Bannon ve Britt, 2014);

- dersle ilişkili yönetim; oyun oynama, müzik dinleme, video izleme gibi eğlence amaçlı (Alarabiat ve Al-Mohammad, 2015),

- tercüme, imla kontrolü, kelime arama ve sözlüğe erişim amaçlı (Al Hamdani, 2014);

- doküman paylaşımı, akademisyen ve öğrencilerin paylaştıkları dokümanların senkronize edilmesi, saklaması ve geri getirilmesi (Johnston, 2016)

şeklinde sıralanabilir. Wang vd. (2009) ise, sınıfta akıllı cep telefonu kullanımının insan davranışları üzerindeki etkisini performans beklentisi (mobil öğrenmenin algılanan yararı), çaba beklentisi (kullanıcılar tarafindan algılanan öğrenme için akıllı cep telefonu kullanmanın kolaylığı), sosyal etki (diğer insanların mobil ortamda öğrenmeyi nasıl uyum sağladıklarına dair inanç), algılanan eğlence (öğrenme süreci dışında akıllı cep telefonu kullanma eğlencesi) ve öğrenmenin öz yönetimi (otantik öğrenme ortamına bağlanma sürecinde bir bireyin kendine özgü biçimde kendini nasıl hissettiğini ifade etmesi) şeklinde sınıflandırmıştır.

Bu kadar çok ve çeşitli kullanım amacına sahip akıllı cep telefonlarının yaygınlaşmasının bir göstergesi de Smith vd.'nin (2015) yaptığı çalışma ile gözler önüne serilmektedir. Bu çalışmaya göre akıllı cep telefonu sahibi olduğunu beyan eden lisans öğrencilerinin \%99'unun derslerinin son bir saati içinde en az bir kez cep telefonlarını kullandıklarını belirtmişlerdir. Ne var ki, alanyazın incelendiğinde, yukarıda da belirtildiği üzere, eğitim ortamlarında akıllı cep telefonu kullanımına olumlu ve olumsuz olarak bakan iki zıt görüş olduğu ancak araştırmaların çoğunun olumsuz görüşe odaklandığı görülmüştür. Olumsuz olarak bakan çalışmaların da iki savı söz konusudur: Birincisi aşırı kullanımdan kaynaklanan bağımlılık, diğeri ise yine aşırı kullanımın ortaya çıkardığı ve akıllı cep telefonlarının olanak sağladığı birden fazla işi ayna anda yapmayı ifade eden çoklu-görevin bölünmeye ve dikkat dağınıklığına sebep olması şeklindedir. Bölünme ve dikkat dağınıklığının sonucunda ise ders 
sürecinin doğal akışının bozulması söz konusudur. Her iki olumsuz durumun sonucu, ders başarısında düşüş olarak karşımıza çıkmaktadır. Bu durumları ortaya koyan bazı çalışmalara ilişkin kısa açıklamalara aşağıda değinilmiştir.

Alan yazına göre internet bağımlılığı, mobil bağımlılık ve akıllı cep telefonu bağımlılı̆̆ının tanımları farklıdır (Lee, vd., 2015). Hwang, Son ve Choi (2011), akıllı cep telefonu bağımlılığın düzeyini, akıllı cep telefonuna bağlı olma, obsesif kullanma durumu ve günlük yaşamı sıkıntıya sokma olarak ifade etmektedir. Yoon vd.'nin (2011) tanımında ise cep telefonu yoksunluğunun sinirlilik ve kaygı bozukluğuna ve işe yoğunlaşamamaya yol açmasına dikkat çekilmektedir. Felisoni ve Godoi (2018), akıllı cep telefonları ya da diğer teknolojilerin kullanımının akademik performans üzerindeki olumsuz etkisinin "aşırı" kullanımına bağlı olabileceğini düşünmektedir. Akıllı cep telefonlarının ya da diğer teknolojilerin aşırı kullanımının öğretim elemanlarının dikkatinin fazlaca dağılmasına, derse ve diğer sınıf etkinliklerinin kalitesine olumsuz yansımasına sebep olabileceğini düşünmektedir. Bu tür teknolojileri çok yoğun kullanan öğrencilerin sınıftaki diğer öğrencileri de uygulama kontrolü, anında mesaj vb. başka yollarla "dürtebileceklerini” iddia etmektedir. Bunun yanı sıra bazı cep telefonu uygulamalarının diğerlerine göre daha zararlı olabileceğini düşünmektedirler. Tesch, Coelho ve Drozdenko (2011) sadece kişisel teknoloji kullanımının değil başkalarının da teknoloji kullanımının (telefonun çalması, vb.) dikkat bölünmesine neden olacağına dikkati çekmektedir. Yapılan araştırmalara göre, öğrenciler belli bir kullanım politikası ya da uygun bir denetleme olmadığında, öğretmenin sınıfta dolaşması ya da büyük/kalabalık sınıflar gibi cep telefonu kullanımının dikkat çekmeyeceğini düşündüğü durumlarda cep telefonlarını daha sıklıkla kullanmaktadır (Mitchell, Finkelhorve Wolak, 2005).

Lee, Cho, Kim ve Noh'un (2015) çalışmasında üniversite öğrencilerinin akıllı telefonlarına bağımlılık düzeylerine odaklanılmış ve akıllı cep telefonu bağımlılı̆̆ı seviyesine dayalı olarak kendinden kontrollü öğrenme ile öğrenme akışı arasındaki fark anlaşılmaya çalışılmıştır. Öğrenme akışı, bir etkinliğe dahil olunduğunda, insanların tamamen konsantre olması ve keyif alması (Csikszentmihalyi, 1990) ve duygusal ya da davranışsal olarak çaba göstermesi (Marks, 2000) olarak tanımlamaktadır. Akışın sağladığı keyif ile öğrencinin doyum düzeyinin, öğrenme kalitesinin ve öğrenme sonuçlarının artması söz konusudur (Kim, Tak ve Lee, 2010). 210 öğrenci ile yürütülen çalışmada, üst düzeyde bağımlılığı olan öğrencilerin kendinden kontrollü öğrenmelerinin düşük, benzer şekilde çalışma sırasında akışın düşük olduğu görülmüştür. Lee, vd.'nin (2015) çalışmasında ise akıllı cep telefonu bağımlısı öğrencilerin çalışırken düzenli olarak telefonlardaki farklı uygulamalarla bölündüğü ve cep telefonundan öğrenme ile ilgili planları üzerinde kontrollerinin olmadığı görülmüştür. Bununla birlikte akıllı cep telefonunu aşırı kullananların günlük yaşamlarında sosyal problem yaşadıkları da görülmüştür.

Junco ve Cotten'ın (2011) çalışmasına katılan 1839 Amerikalı üniversite öğrencisi arasından günlük olarak akıllı cep telefonu ile oldukça uzun zaman geçirenlerin ortalama akademik başarılarında tersi oranda düşüş olduğu gözlenmiştir. Duncan, Hoekstra ve Wilcox’un (2012), üniversite öğrencileri ile gerçekleştirdikleri çalışmalarında ise derste cep telefonu kullanımı ile final notları arasında ters yönde ilişki olduğu görülmüştür.

Rosen, Carrier ve Cheever'in (2013) çalışmasında ise 11-25 arası 263 Amerikalı öğrenci içinde çalışırken Facebook kullanan ve mesajlaşan öğrencilerin bunları yapmayanlara göre ortalama akademik başarı puanlarının daha düşük olduğu görülmüştür. Felisoni ve Godoi, (2018) çalışmalarında öğrencilerin cep telefonlarında geçirdikleri süreyi anlamak amacıyla 'Moment' ve 'App Usage Tracker' isimli iki uygulama kullanmışlardır. Brezilya'daki İşletme Okulu’na kayıtlı 250 öğrencinin akıllı cep telefonu kullanımına harcadıkları süre ile akademik başarılarını karşılaştırdıklarında her 100 dakikaya karşılık okul başarısının 6.3 puan düştüğü görülmüştür. Üstelik bu oran ders esnasında kullanım göz önünde bulundurulduğunda iki katı kadar artmaktadır.

Eğitim ortamlarında akıllı cep telefonu kullanımına olumsuz bakmanın bir de duygusal yönü vardır. Abramova, Baumann, Krasnov ve Lessmann’ın (2017) 60 üniversite öğrencisi ile gerçekleştirdikleri çalışmada, akademik ortamlarda "phub” eylemi tartışılmıştır. "Phub” eylemi, Cambridge Sözlüğü’nde birlikte olunan kişiyi görmezden gelip, onun yerine kendi cep telefonu ile ilgilenmek olarak tanımlanmaktadır. MacMillan sözlük ise bu eylemi kaba bir davranış olarak nitelendirmektedir. Gözlem, anket ve odak grup görüşmeleri ile gerçekleştirilen bu çalışmada, öğrencilerin cep telefonu kullanımlarının ders zamanından önemli ölçüde çaldığını ve genellikle bu davranışın öğrenme sürecindeki etkisini hafife aldıklarını göstermektedir. Bu çalışma, öğrencinin ders sırasında akıllı cep telefonuna bakma sayısının görsel dikkat ile olumsuz bir şekilde ilişkili olduğunu gösterirken akıllı cep telefonu kullanımının toplam süresinin ise işitsel dikkati kötüleştirdiğini ortaya koymaktadır.

Akıllı cep telefonlarının çoklu görev özelliğine gelinecek olursa, Chen ve Yan (2016) bu özelliği bir örnekle açıklamaktadır. Bireylerin makale okurken düzenli ve sürekli olarak e-postalarını kontrol etmelerini çoklu görevi olarak tanımlarlarken, mobil telefonlarından öğrenme amacıyla makale okumayı ise mobil öğrenme olarak 
tanımlamaktadırlar. Her ne kadar çoklu-görev yeni bir fenomen olmasa da, insanların eş zamanlı olarak gerçekleştirebilecekleri dijital etkinlik sayısı ve türünde artış söz konusudur. Yetişkin ve genç öğrenenlerin öğretim bağlamlarında, yeni teknolojilerin erişilebilirlik, algılanan kullanım kolaylığı ve çok sayıdaki etkinlik yelpazesi, görev dışı davranışlara bağlanmalarını kolaylaştırır (Wood, vd., 2012).

Wood vd. (2012), çoklu görevi birden fazla işi aynı zamanda yapma olarak tanımlamaktadır. Junco (2012) ise "öğrenme durumlarında gerçekleştirilen iyi yapılandırılmamış ve sıralı olmayan görevler arasındaki geçiş ve bölünmüş dikkat” olarak tanımlamaktadır. Bu tanımdan yola çıkarak Wood vd. (2012) bilginin işlenmesinin daha çok zaman alacağını, Chen ve Yan (2016) ise uyaranlar arası geçiş sürecinde bazı bilgilerin kaybolabileceğini dile getirmektedir. Teknoloji ile birlikte gerçekleştirilen çoklu görevler, akademik bağlamda verimlilik ve üretkenliği olumsuz yönde etkileyebilmektedir (Karpinski, Kirschner, Ozer, Mellott ve Ochwo, 2013). Chen ve Yan (2016), 1999-2014 yılları arasındaki konu alanı ile ilgili basılan 132 çalışmayı incelemiş ve mobil telefon kullanımının çoklu görevin dikkat dağınıklığına yol açmasını; dikkat dağınıklığının kaynakları (telefonun çalması, sosyal uygulamalar ve mesajlaşma), dikkat dağınıklığının hedefleri (okuma ve katılma) ile dikkat dağınıklığının konusu (kişilik, cinsiyet ve kültür) olmak üzere üç başlıkta toplamıştır.

Araştırmaların çoğu sınıfta mobil telefon kullanımının dikkat dağınıklığına sebep olduğunu (Baker, Lusk ve Neuhauser, 2012; Dietz ve Henrich, 2014; Hawi ve Samaha, 2016; Kim, vd. 2017; Lenhart, Ling, Campbell ve Purcell, 2010; McCoy, 2013; Thomas vd., 2014), sınıfta mesajlaşmanın öğrenci performansını düşürdüğünü (Dietz ve Henrich, 2014; Rosen, Lim, Carrier ve Cheever, 2011) ortaya koymaktadır. Kim, Jung, Jung, Ko ve Lee (2017), kolej öğrencilerinin sınıf dışında görev-dışı, çoklu görev özellikleri ile akıllı cep telefonu kullanımlarını irdelemek üzere 47 öğretim elemanı ve 283 öğrenci üzerinde ön görüşme yapmışlar, ardından geliştirdikleri Let's FOCUS isimli bir yazılımı Kore Üniversitelerinden birinde gönüllülerin denemesini sağlamışlardır. 233 sınıfta 370 öğrenci, indirdikleri bu uygulamayı 9335 saat kullanmıştır. Kim vd. (2017) ile Hawi ve Samaha (2016), çoklu görevlerin bilişsel işleme ihtiyaç duyduğunu bu da bilişsel olarak aşırı yüklenmeye sebep olabileceğini dile getirmektedir. Örneğin arkadaşından gelen bir mesaja cevap yazan bir öğrenci, öğretim elemanını dinlemeyi bir süreliğine kesecektir. Ophir, Nass ve Wagner (2009) ise ağır çoklu görevlilerin hafif çoklu görevlilere göre, alakasız bilgiyi süzmede daha az başarılı olduğunu ve görevler arasında geçişlerde daha yavaş olduğunu ortaya koymaktadır. Just, Carpenter, Keller, Emery, Zajac ve Thulborn'a göre (2001) akıllı cep telefonu kullanıp öğrenme sırasında bildirimlerle kesintiler uğramayı kabul eden ve öğrenme süreçlerini keserek akademik olmayan bu görevlere geçiş yapan öğrencilerin, öğrenmelerinde kayıplar olacaktır (Hawi ve Samaha 2016). Mevcut akıllı cep telefonlarındaki öğrenmeyi verimli kılan araçların varlı̆̆ı, yeni öğrenilenlerin pekiştirilmesinde, öğrenci ve öğretim elemanları ile etkileşimde kullanıldığı düşüncesinin aksine, sınıfta ya da çalışma ile ilgili başka herhangi bir ortamda bölünmeye neden olmaktadır (Felisoni ve Godoi, 2018).

Lepp, Barkley ve Karpinski’nin (2014) 536 Amerikalı üniversite öğrencisi ile geniş çaplı gerçekleştirdikleri çalışmalarında, mesajlaşmanın ortalama akademik başarı ve ile ters, kaygı bozukluğu ile pozitif yönde ilişkisi olduğu, akademik başarının hayattan doyum ile olumlu, kaygı bozukluğu ile ters yönde ilişkisi olduğunu ortaya koymuştur. Wood, Zivcakova, Gentile, Archer, De Pasquale ve Nosko'nun (2012) çalışmasına göre e-posta, mesajlaşma, Facebook vb. teknolojilerle çoklu görev gerçekleştirmenin etkili öğrenmeyle olumsuz ilişkisi vardır ve düşük test sonuçları ile sonuçlanmaktadır. Anında mesajlaşma ise ciddi bir dikkat dağıııcı olarak karşımıza çıkmaktadır (Junco ve Cotten, 2011).

Bir taraftan sınıfta ya da sınıf dışı öğrenme ile ilgili durumlarda akıllı cep telefonu kullanımının olumsuz yönlerine dikkat çekilirken, bu olumsuzluğun tersi yönde önlenemez şekilde kullanımı da aşikardır. Örneğin her ne kadar Facebook'un temel kullanım amacı sosyalleşme ve eğlence olsa da, artan sayıda öğrencinin Facebook'tan akademik amaçlı yararlandığı ve çalışma grupları ve buluşmalar ayarladığı bilinmektedir (Alarabiat ve AlMohammad, 2015; Johnston, Chen ve Hauman, 2013). 2011 y1lında akıllı cep telefonu sahibi olduğunu söyleyen lisans öğrencilerinin sayısı \% 55 'ten, 2012 yılında \%62'ye çıkmıştır. Akademik amaçlı akıllı cep telefonu kullanımı oranı 2011 yılında \%37'den 2012 yılında iki katına kadar (\%67) artış göstermiştir (Dahlstrom, 2012).

Akademisyenlerin çoğunun Youtube'un aktif kullanıcıları haline geldiği (Roodt, de Villiers, Johnston, Ophoffve Peier, 2014) ve Wiki'lerin öğrencilerin grup çalışmasındaki etkililiği (Burton, 2015) göz ardı edilemez. Kuznekoff, Munz ve Titsworth (2015), öğrencilerin derste mesajlaşmalarına ve tweet atmalarına izin verilmesinin ders başarısını düşürmeye neden olmasına karşın, bu cihazların derse doğru şekilde entegrasyonun öğrencilerin öğrenmesine yardımcı olacağını dile getirmektedirler. Akıllı cep telefonlarının çoklu görev özellikleri eğitim amaçlı kullanımı sınıf içi öğrenmelerde, sınıf dışı çalışmalarda, bireysel ya da grup çalışmalarında ve ödev 
yaparken (Jacobsen ve Forste, 2011; Junco, 2012) kullanılabilir. Bolliger ve Shepherd (2016), internete bağlanmayı olanaklı kılan aygıtların, anındalık ve doğrudan deneyim özellikleri yoluyla ile öğrenmeye katkı sağladıklarını savunmaktadır ve İnternet'e bağlanmayı olanaklı kılan araçların olumlu yanları, olumsuz yanları dikkate alınarak dengelenmelidir demektedir.

Thomas ve Orthober (2011), mesajlaşmanın öğretmen, öğrenci ve içerik arasında etkileşim, iletişim ve işbirliği sağladığını dile getirmektedir. Ayrıca Ruggiero ve Mong (2015), sınıfta mobil cihazların kullanımını kağıttan kurtulmaya ve "yeşil" sınıflara dönüşmeye olanak sağlamak gibi olumlu beklenmeyen bir etkisinin olacağını öne sürmektedir. Johnston (2016), herhangi bir akademisyenin ya da öğrencinin sınıfta mobil cihazları kullanmak istememesinin imkansız olduğunu öne sürmektedir. Gerek akademisyenlerin gerekse öğrencilerin bu cihazlarla aldıkları notların kaybolmasına imkan yoktur, ayrıca kötü el yazısı nedeniyle anlam kaybı olmaz.Bu şekilde, kağıtsız “yeşil” sınıflara dönüşüm söz konusu olur ve tüm dokümanlar paylaşlabilir, her zaman erişilebilir. Üstelik, birçok insan akıllı cep telefonlarını kullanarak eriştikleri İnternet'ten elde etikleri bilgiler yoluyla yeni bilgiler üretmektedir (Anshari, Almunawar, Shahrill, Wicaksono ve Huda, 2017). Chen ve Tzeng (2010), internette sık sık bilgi arayan öğrencilerin daha az arayan öğrencilere göre daha başarılı olduklarını ortaya koymuştur.

Kuznekoff, Munz ve Titsworth'un (2015), 8 grup üzerinde gerçekleştirdikleri çalışmalarında, kontrol ve deney gruplarına bakıldığında, derste tweet atan veya alakasız mesajlara cevap veren öğrencilere göre bu davranışı sergilemeyen öğrenciler \%10-17 daha yüksek bir harf notu elde ettiği, bilgiyi geri çağırma konusunda \%70 ve not almada \%50 daha yüksek puan aldığı görülmüştür. Sınıf içeriğiyle alakasız mesajlar göndermek/almak, öğrenme ve not alımı üzerinde olumsuz etkilere neden olurken, ilgili mesaj gönderiminin ise önemli bir olumsuz etkisi olmadığı ortaya çıkmıştır. Judd (2014), öğrencilerin çalışmalarında Facebook kullanımının çoklu görev becerisine önemli katkılar sağladığını ortaya koymaktadır.

Felisoni ve Godoi (2018) geçmiş çalışmalardan yola çıkarak zaman yönetimi becerisi ile akıllı cep telefonu kullanımı arasında ilişki olabileceğini hatta bu değişkenlerin odaklanma ve dikkati de düzene koyacağını düşünmektedir. Yine Felisoni ve Godoi (2018) alanyazındaki çalışmalarda akıllı cep telefonu kullanımının düşük akademik beceriye yol açmasına farklı bir bakış açısı getirerek belki de düşük akademik beceriye sahip bireylerin daha çok akıllı cep telefonu kullandıklarının sorgulanması gerektiğini de ifade etmektedirler. Chen ve Yan (2016), çoklu görevlerin öğrenme üzerindeki etkisini araştırırken, farklı görevlerin etkisine bakmanın önemli olduğuna dikkat çekmektedir. Bunu da işitsel ve görsel görevlerle açıklamaktadır. Sözel olarak dinlenilen bir dersin notunu alırken sesli mesaj dinlemek, dikkatin dağılmasına yol açabilecekken, sözel olarak dinlenilen dersin notunu alırken arkadaşının gönderdiği görsele bakmanın daha kolay olabileceğini ifade etmektedir.

\section{Araştırmanın amacı}

Chen ve Yan (2016), bu alana ilişkin alanyazın taraması yapma gerekçelerini akıllı cep telefonlarının günlük yaşamdaki yerinin eğitim ortamlarında da vazgeçilmez hale gelmesi sonucunda öğrenme sürecinde akıllı cep telefonlarının çoklu görev özelliğinin kullanımı, bu sürecin karmaşıklığı ve bu durum ele alınmasının aciliyeti şeklinde sıralamaktadır. Lisansüstü öğrencilerin bu duruma karşı bakış açılarının ortaya konulması aynı nedenlerden ötürü bu çalışmanın motivasyon kaynağı olmuştur. $\mathrm{Bu}$ araştırmanın amacı, yüksek lisans öğrencilerinin eğitim süreçlerinde akıllı cep telefonu kullanımının olumlu etkilerine yönelik görüşleri nelerdir sorusuna cevap aramaktır.

\section{Yöntem}

Bu başlıkta, araştırmanın deseni, çalışma grubu ve veri toplama aracına yer verilmiştir.

\section{Araştırma Deseni}

Cresswell (2003), belirli bir zaman diliminde bir durumun derinlemesine incelenmeye çalışılması söz konusu olduğunda nitel araştırma yöntemlerinden Durum Çalışmasının uygun olacağını ifade etmektedir. Bu çalışmada akıllı cep telefonu kullanımının olumlu etkileri bütüncül bir yaklaşımla el alınmaya çalışılmış ve öğrencilerin bu durumdan nasıl etkilendiği ortaya konulmaya çalışılmıştır. Bu araştırmada tek bir durum ele alındığı için Yin'in (2013) Durum Çalışması sınıflamasından Tip 1 benimsenmiştir.

\section{Çalışma Grubu}

Araştırmanın çalışma grubuna ulaşmak için Ankara'nın köklü üniversitelerinden birinin Eğitim Bilimleri Enstitüsünde yer alan 10 farklı anabilim dalında yüksek lisans ve doktora dersi yürüten öğretim üyelerinden 
derslerine devam etmekte olan ve bu çalışmaya gönüllü olarak katılmak isteyebilecek öğrencilerine e-posta ile davet göndermeleri istenmiştir. Çalışmaya 29 öğrenci gönüllü olarak katkı sağlamıştır.

Katılımcıların yaş dağılımları Tablo 1'de sunulmuştur.

Tablo 1. Katılımcıların Yaş Dağı̆lımları

\begin{tabular}{lc}
\hline Yaş & f \\
$21-24$ & 19 \\
$25-28$ & 6 \\
$>28$ & 4 \\
Toplam & 29 \\
\hline
\end{tabular}

Tablo 1 incelendiğinde katılımcıların çoğunun $(n=19)$ 21-24 yaş aralığında olduğu görülmektedir. 25-28 yaş aralığında 6,28 yaş ve üzerinde ise 4 katılımcı bulunmaktadır. Katılımcıların yüksek lisans öğrencisi olduğu düşünüldüğünde katılımcılarının çoğunluğunun 21-24 yaş arasında olması beklenilen bir durumdur. Katılımcıların 20'si kadın 9'u ise erkektir.

Katılımcıların kayıtlı olduğu program dağı̆lımları Tablo 2'de sunulmuştur.

Tablo 2. Katılımcıların Kayıtlı Oldukları Programların Dağılımları

\begin{tabular}{lc}
\hline Program & f \\
Sosyal Bilgiler Eğitimi & 9 \\
Fen Bilgisi Eğitimi & 4 \\
Sinıf Eğitimi & 4 \\
Matematik Eğitimi & 3 \\
Kimya Eğitimi & 3 \\
Fizik Eğitimi & 2 \\
Bilgisayar ve Öğretim Teknolojileri Eğitimi & 2 \\
Biyoloji Eğitimi & 2 \\
Toplam & 29 \\
\hline
\end{tabular}

Tablo 2 incelendiğinde katılımcıların; Sosyal Bilgiler Eğitimi (n=9), Fen Bilgisi Eğitimi (n=4), Sınıf Eğitimi $(\mathrm{n}=4)$, Matematik Eğitimi $(\mathrm{n}=3)$, Kimya Eğitimi $(\mathrm{n}=3)$, Fizik Eğitimi $(\mathrm{n}=2)$, Bilgisayar ve Öğretim Teknolojileri Eğitimi (n=2), Biyoloji Eğitimi (n=2) bölümlerinden oldukları görülmektedir. 29 katılımcının 15'i tam, biri yarı zamanlı çalışıyorken 12'si ise çalışmadığını ifade etmiştir.

Katılımcıların sahip oldukları akıllı cep telefonu markası dağı̆lımları Tablo 3'te sunulmuştur.

Tablo 3. Katılımcıların Akıllı Cep Telefon Markası Dağılımları

\begin{tabular}{lc} 
Marka & f \\
Iphone & $12^{*}$ \\
Samsung & 8 \\
LG & $5^{*}$ \\
Sony & 2 \\
Asus & 1 \\
Huawei & 1 \\
Xiaomi & 1 \\
Toplam & 30 \\
\hline
\end{tabular}

* Bir kişinin iki telefonu var

Tablo 3 incelendiğinde katılımcıların; sirasıyla Iphone ( $\mathrm{n}=12)$, Samsung $(\mathrm{n}=8), \mathrm{LG}(\mathrm{n}=5)$, Sony $(\mathrm{n}=2)$, Asus $(\mathrm{n}=1)$, Huawei $(\mathrm{n}=1)$ ve Xiaomi $(\mathrm{n}=1)$ marka akıllı cep telefonu kullandıkları görülmektedir. Bir katılımcı ise 2 telefona sahip olduğunu bildirmiştir.

Katılımcıların günlük akıllı cep telefonu kullanım süresi dağılımları Tablo 4'te sunulmuştur. 
Tablo 4. Katılımcıların Akıllı Cep Telefonu Kullanım Süresi Dağılımları

\begin{tabular}{lc} 
Süre & f \\
$1-2$ saat & 4 \\
$2-4$ saat & 8 \\
$4-6$ saat & 7 \\
6-8 saat & 6 \\
Sürekli kullanırım & 4 \\
Toplam & 29 \\
\hline
\end{tabular}

Tablo 4 incelendiğinde katılımcıların 4'ünün akıllı cep telefonunu günde iki saatten az, 8'inin 2-4 saat, 7'sinin 4-6 saat ve 4'ünün ise 6 saatten fazla kullandığı görülmektedir. Aljomaa, Al.Qudah, Albursan, Bakhiet ve Abduljabbar'ın (2016) araştırmasının sonuçları da bu çalışmayı destekler niteliktedir. Aljomaa vd.nin araştırmasında 416 üniversite öğrencisinin akıllı telefonu bağımlılığını belirlemeye çalışmışlar ve öğrencilerden 37 'sinin günde 2 saatten az, 110'unun 2-4 saat ve 269'unun günde 4 saatten fazla akıllı telefonların kullandıkları belirlemişlerdir.

\section{Veri Toplama Aracı}

Araştırmada yüksek lisans öğrencilerine ulaşmak hedeflenmiş ve bu hedef kitleye ders veren öğretim üyelerinden öğrencilerine ulaşmaları istenmiştir. Araştırmaya katılmayı kabul eden öğrencilerin görüşlerini elde edebilmek için bir görüş formu hazırlanmıştır. Görüş formu hazırlanırken alanyazından benzer çalışmalar (Anshari, vd., 2017; Bolkan ve Griffin, 2017; Kim, vd., 2017; Muñoz ve García, 2016; Wood, vd., 2012) dikkate alınarak sorular oluşturulmuştur. Sorular öğrencilerin akıllı cep telefonlarını eğitim amaçlı kullanım gerekçeleri, akademik performanslarına etkisi, kendilerini güvende hissetmelerini sağlaması gibi konuları içermektedir. Görüş formu, kapsam ve ifade açısından Bilgisayar ve Öğretim Teknolojileri Eğitimi alanında öğretim üyesi olarak çalışan iki uzmanın görüşüne başvurulmuştur. Uzman görüşlerine göre son hali verilen Görüş formu, katılımcıların genel özelliklerinin belirlenmesine yönelik 7 soru ve öğrencilerin görüşlerinin elde edilmesine yönelik 7 sorudan oluşmaktadır.

\section{Bulgular}

Araştırmanın amaçlarına yönelik ulaşılan bulgular, aşağıda sunulmaktadır.

Katılımcıların, "Yüksek lisans derslerinizde, ders sirasinda akıllı cep telefonlarınızı kontrol eder misiniz ya da kullanır mısınız? Bu davranışınızın gerekçesi ne olabilir?" sorusuna 29 katılımcıdan 3'ü (1 Kadın, 2 Erkek) kullanmam cevabı vermiştir. Kullanırım cevabını veren katılımcıların kullanım gerekçelerine ilişkin vermiş oldukları cevaplar ise Tablo 5'te sunulmuştur.

Tablo 5. Katılımcıların Derste Akıllı Cep Telefonu Kullanım Gerekçeleri

\begin{tabular}{lc} 
Kullanım Gerekçesi & f \\
Gelen bildirimleri kontrol ederim. & 10 \\
Saate ya da takvime bakarım. & 8 \\
Derste geçen bir konu ya da terimi araştırırım. & 8 \\
Acil arama yaparım. & 5 \\
Merak/alışkanlık/bağımlılıktan ötürü kullanırım. & 5 \\
Kişisel amaçla kullanırım. & 4 \\
Sıkılınca kullanırım. & 2 \\
Tablo 5 Devamı & 2 \\
\hline İş ile ilgili kullanırım. & 1 \\
Not alırım. & 1 \\
Derste Kullanmıyorum. & 1 \\
Dikkat çekmeyeceğini düşündüğüm zaman kullanırım &
\end{tabular}


Tablo 5 incelendiğinde katılımcıların ders sırasında cep telefonlarını çoğunlukla gelen bildirimleri kontrol etmek için $(n=10)$, saate ya da takvime bakmak için $(n=8)$, derste geçen bir konu ya da terimi araştırmak için $(n=8)$, acil arama yapmak için $(n=5)$, merak/alışkanlık/bağımlılık $(n=5)$ nedeniyle ya da kişisel amaçlar için $(n=4)$ kullandıkları görülmektedir. Katılımcıların ikisi sıkılınca akıllı cep telefonlarına baktıklarını açıkça ifade etmiştir, gelen bildirim kontrolü ya da saatin kontrolü de sıkılmalarından kaynaklanıyor olabilir. Bolkan ve Griffin (2017), Keller'in 1987 yılındaki güdülenme ile ilgili görüşüne atıfta bulunarak, öğrencilerin ilgilerini öldürmediğimiz sürece sıkılmalarını önleriz görüşünün bugün hala bir problem olarak eğitimcilerin önünde bulunduğuna dikkat çekmektedir. Pekrun, Goetz, Daniels ve Stupinsky (2010), Nett, Goetz ve Hall (2011), Mann ve Robinson (2009), Goetz ve Hall (2014) gibi araştırmacılar, derslerin çoğunda öğrencilerin genelinin sıkıldığına dikkat çekmektedir. Emanuel (2013) ve McCoy (2013) gibi araştırmacılar da öğrencilerin sınıfta sıkıldıklarında cep telefonlarına sığındıklarını işaret etmektedirler. Ayrıca bir katılımcı da akıllı cep telefonunu dikkat çekmeyeceğini düşündüğü zaman kullandığını belirtmiştir. Mitchell, Finkelhor ve Wolak'ın (2005) yapmış oldukları araştırmada da öğretmenin cep telefonu kullanımını fark etmediği durumlarda öğrencilerin cep telefonlarını daha sık kullandıkları gözlenmiştir. Yıldırım, vd.'nin (2016) de araştırmasının hedef kitlesi her ne kadar ortaokul ve lise öğrencileri olsa da bulguları bu araştırma ile tutarlıdır. Ayrıca Gökdaş vd.'nin (2014) araştırmasında öğretmen adaylarının zaman planlama amacı ile akıllı cep telefonlarını kullandıklarını dile getirmeleri de bu araştırmayı destekler niteliktedir.

Katılımcıların, "Yüksek lisans derslerinizde akıllı cep telefonunuz ile uğraşmanız performansınızı nasıl etkilemektedir? Cep telefonlarınızı kontrol etmeniz hızlı bir biçimde rahatlamanıza mı sebep olmakta ya da sizin ders konsantrasyonunuzun bölünmesine mi sebep olmaktadır? " Sorusuna ilişkin vermiş oldukları cevapları Tablo 6'da sunulmuştur.

Tablo 6. Katılımcıların Derste Akıllı Cep Telefonu Kullanımının Dersteki Performanslarına Etkisi

\begin{tabular}{lc}
\hline Performansa Etkisi & f \\
Performansıma etkisi yok. & 9 \\
Rahatlıyorum. & 7 \\
Nadiren performansımı etkiliyor. & 5 \\
Telefondan uzak durduğum zaman aklım kalıyor. & 4 \\
Performansımı olumsuz etkiliyor. & 4 \\
Motivasyonumu artırıyor. & 3 \\
Toplam & 32 \\
\hline
\end{tabular}

Tablo 6 incelendiğinde katılımcıların büyük bir kısmı derste akıllı cep telefonu kullanmanın performanslarını etkilemediğini $(n=9)$ ya da rahatladıklarını $(n=7)$ belirtmiştir. Bunların yanı sıra katılımcılar; derste akıllı cep telefonu kullanımının nadiren performanslarına etki ettiğini $(n=5)$, telefonlarına erişemediklerinde akıllarının kaldığını $(n=4)$, performanslarını olumsuz etkilediğini $(n=4)$ ve motivasyonlarını arttırdığını ( $n=3)$ ifade etmiştir. Alanyazına bakıldığında bu çalışmanın aksine araştırmaların çoğunda (Dietz ve Henrich, 2014; Rosen, Lim, Carrier ve Cheever, 2011) daha önce de belirtildiği gibi sınıfta telefon kullanımının öğrenci performansını düşürdüğü sonucuna varılmıştır. Bu araştırmadaki bulgunun alanyazın ile çelişmesi; araştırmaya katılanların lisansüstü öğrencisi olmalarından ötürü farkındalık düzeylerinin yüksek olması ve bu nedenle performanslarını olumsuz etkilememesi olabilir. Bir başka bakış açısıyla bu araştırmada lisansüstü öğrencilerinin beyanları esas alınmıştır ancak katılımcıların gerçek yaşam davranışları ile beyanları, Duncan, Hoekstra ve Wilcox'ın (2012) araştırmalarında da görüldüğü gibi, farklı olabilmektedir.

Katılımcıların "Ders esnasında cep telefonunuzun yanınızda olması kendinizi güvende hissetmenizi sağllyor mu? Nedenini açıklayınız. ” sorusuna ilişkin vermiş oldukları cevapları Tablo 7'de sunulmuştur.

Tablo 7. Katılımcıların Derste Akıllı Cep Telefonu Kullanımının Güven Duygusuna Etkisi

$\begin{array}{lc}\text { Güven Duygusuna Etkisi } & \text { f } \\ \text { Kendimi güvende hissediyorum. } & 23 \\ \text { Güven duygusu sağlamiyor. } & 5\end{array}$


Derste Kullanmiyorum. 1

Toplam

Tablo 7 incelendiğinde katılımcıların çok büyük bir kısmı derste akıllı cep telefonlarını kullanmanın kendilerini güvende hissettirdiğini ( $\mathrm{n}=23$ ) belirtmiştir. 5 katılımcı ise akıllı cep telefonu kullanmanın herhangi bir güven duygusu sağlamadığını ifade ederken bir katılımcı ise ders sırasında akıllı cep telefonu kullanmadığını belirtmiştir. Alanyazına bakıldığında Johnston (2016), Afrika (Güney Afrika) ve Avrupa'da (Almanya) yüksek lisans düzeyinde öğrenim gören öğrenciler üzerinde web destekli mobil araçların kullanımının etkisi ve istenmeyen sonuçları üzerinde gözlem ve etkileşim yoluyla bir çalışma yürütmüştür. Mobil cihazların sınıfı olumsuz etkilemediğinin görüldüğü araştırma sonuçları aksine öğrencilerin mobil cihazlara erişim hakkı tanındığında daha çok bağlandığını ve daha rahat hissettiklerini ortaya koymuştur

Katılımcıların, "Yüksek lisans derslerinizde cep telefonlarınızı eğitim amaçlı nasıl kullandı̆̆ınızı açıklar misinız?" sorusuna ilişkin vermiş oldukları cevapları Tablo 8'de sunulmuştur.

Tablo 8. Katılımcıların Derste Akıllı Cep Telefonlarını Eğitim Amaçlı Kullanımları

\begin{tabular}{lc} 
Eğitim Amaçlı Kullanım & f \\
Derste geçen bir konu ya da terimi araştırıım. & 21 \\
E-posta gönderip-alıım. & 6 \\
Ders materyallerini takip ederim. & 5 \\
Tez, makale incelerim. & 5 \\
Not alırım. & 4 \\
Ses kaydederim. & 2 \\
Çeviri için kullanırım. & 1 \\
Tahtanın fotoğrafını çekerim. & 1 \\
Toplam & 45 \\
\hline
\end{tabular}

Tablo 8 incelendiğinde katılımcıların çok büyük bir kısmının akıllı telefonlarını derste geçen bir konu ya da terimi araştırmak $(\mathrm{n}=21)$ için kullandıklarını belirtmiştir. Diğer kullanım amaçlarını ise e-posta göndermek ve almak $(n=6)$, ders materyallerini takip etmek $(n=5)$, tez-makale incelemek $(n=5)$, not almak $(n=4)$, ses kaydetmek $(\mathrm{n}=2)$, çeviri için kullanmak $(\mathrm{n}=1)$ ve tahtanın fotoğrafını çekmek $(\mathrm{n}=1)$ olarak ifade etmiştir. Eğitim ortamlarında akıllı cep telefonu kullanımına ilişskin alanyazındaki araştırmalar ile bu araştırmanın bulgularının tutarlı olduğu görülmektedir (Alarabiat ve Al-Mohammad, 2015; Al Hamdani, 2014; Anshari, vd., 2017; Au, Lam ve Chan, 2015; Corbeil ve Valdes-Corbeil, 2007; Echeverri, 2011; Kukulska-Hulme, 2007; Nakamura, Hanamitsu ve Minamizawa, 2015; O'Bannon, Dunn ve Park, 2017; Yıldırım, Yaşar ve Murat, 2016).

Katılımcıların, "Yüksek lisans eğitiminizde ders sürecinde akıllı cep telefonunuzun hangi özelliklerini kullandığınızı açıklar mısınız?" sorusuna ilişkin vermiş oldukları cevapları Tablo 9'da sunulmuş̧tur.

Tablo 9. Katılımcıların Derste Akıllı Cep Telefonlarının Farklı Özelliklerini Kullanımları

\begin{tabular}{lc}
\hline Akılı Cep Telefonlarının Özellikleri & f \\
İnternet'te arama yaparım. & 19 \\
e-posta gönderip alırım. & 8 \\
Not alırım. & 7 \\
Anlık iletişim (Whatsapp) için kullanırım. & 6
\end{tabular}

Tablo 9 Devamı

$\begin{array}{lr}\text { Fotoğraf/video çekerim. } & 6\end{array}$

Depolama (kayıtlı olan dosyalara ulaşma) için kullanırım. $\quad 6$

Ses kaydı alırım.

Takvim/Hatırlatma/Yapılacak işler için kullanırım.

Saate bakarım. 
Tablo 9 incelendiğinde katılımcılar; akıllı cep telefonlarının İnternet ( $\mathrm{n}=19)$ başta olmak üzere, e-posta $(\mathrm{n}=8)$, not alma $(n=7)$, anlık iletişim $(n=6)$, fotoğraf/video çekme $(n=6)$, depolama $(n=6)$ gibi özelliklerini sıklıkla kullanmaktadır. Bunların dışında ses kaydı alma $(n=3)$, takvim/hatırlatıcı $(n=3)$, saat $(n=3)$ ve sözlük $(n=2)$ gibi özelliklerinden de faydalanmaktadırlar. Alanyazına bakıldığında ise akıllı telefonların ders sırasında kullanımı bakımından tıpkı bu araştırmada olduğu gibi en çok internet erişim özelliğinin tercih edildiği sonrasında ise eposta gönderme/alma, anlık mesajlaşma, not alma ve resim/video çekme gibi özelliklerinin kullanıldığ görülmektedir (Alarabiat ve Al-Mohammad, 2015; Bull ve Thompson, 2004; Echeverria, vd., 2011; HartnellYoung ve Vetere, 2008).

Katılımcıların, "Ders dışında yüksek lisans derslerinizle ilişkili olarak akıllı cep telefonlarınızı kullanır mısınız? Cevabınız evet ise hangi amaçlarla kullanırsınız? Bu kullanımın zaman yönetimi açısından etkilerini açıklar mısınız?” sorusuna 29 katılımcıdan 17'si (13 kadın, 4 Erkek) ders dışında ders ile ilişkili olarak akıllı cep telefonu kullanmanın zamandan tasarruf sağladığını ve verimliliklerini arttırdığını belirtmiştir. Katılımcıların ders dışında akıllı cep telefonu kullanımlarına ilişkin vermiş oldukları cevapları Tablo 10'da sunulmuştur.

Tablo 10. Katılımcıların Ders Dışında Akıllı Cep Telefonlarının Dersle İlişkili Kullanımları

\begin{tabular}{lc} 
Ders Dışında Dersle İlişkili Kullanım & f \\
Çevrimiçi kaynaklara erişmekte kullanırım. & 12 \\
Ders arkadaşları ile anlık iletişim (Whatsapp) için kullanırım. & 5 \\
İnternet’te arama (Yök tez arama, Mendeley, Google Scholar) yaparım. & 4 \\
e-posta gönderip-alırım. & 4 \\
Ses kaydını (daha önce sesli kaydedilmiş konuyu) dinlerim. & 2 \\
Kablosuz ağ paylaşımı yaparım. & 2 \\
Fotoğraf/video çekerim. & 1 \\
Toplam & $\mathbf{3 0}$ \\
\hline
\end{tabular}

Tablo 10 incelendiğinde katılımcıların; ders dışında ders ile ilişkili olarak akıllı cep telefonlarını başlıca kullanım gerekçelerinin; çevrimiçi kaynaklara erişim $(n=12)$, ders arkadaşları ile anlık iletişim $(n=5)$, İnternet'te arama yapma $(n=4)$, e-posta gönderme-alma $(n=4)$ olduğu görülmektedir. Bunların dışında ise katılımcılar, ses kaydı dinleme $(n=2)$, kablosuz ă̆ paylaşımı $(n=2)$, fotoğraf/video çekme amacıyla kullandıklarını ifade etmiştir. Anshari, Almunawar, Shahrill, Wicaksono ve Huda'nın (2017) çalışması da bu çalışmayı destekler niteliktedir: Araştırmaya katılan öğrencilerin cep telefonlarını İnternet üzerinden ulaşılabilecek olan bilgilere ve ders materyallerine erişim, sınıf dışında öğretmenleri ile etkileşim, grup ödevlerinin yönetimi amacıyla kullanmaktadır. Benzer şekilde, Muñoz ve García'nın (2016), İspanya'da 2013 yılında 16-30 yaş arasındaki 2000 sosyal medya kullanıcısı ile gerçekleştirdikleri araştırmada sınav zamanı ders çalışırken mobil telefon kullanım amaçlarını, katılımcıların \%34'ü sınıf arkadaşları ile not paylaşımı, \%26'sı internetten bilgi/veri araştırma şeklinde cevaplandırmıştır.

Katılımcıların, “Öğrenci olarak yüksek lisans derslerinizde öğretim üyelerinin ders sırasında akıllı cep telefonlarını kontrol etmeleri ya da kullanmalarına yönelik bakış açınız nedir? “ sorusuna ilişkin vermiş oldukları cevapları Tablo 11'de sunulmuştur.

Tablo 11. Katılımcıların Ders Sırasında Öğretim Üyelerinin Akıllı Cep Telefonlarını Kullanmalarına İlişkin Bakış Açıları

$\begin{array}{lr}\text { Öğretim Elemanının Kullanımına Yönelik Düşünceler } & \text { f } \\ \text { Kullanırlarsa rahatsızlık duymam. } & 14 \\ \text { Acil durum dışında kullanmazlar. } & 8 \\ \text { Amaç dışı kullanımdan rahatsız olurum. } & 4\end{array}$


Ders sürecine olumsuz bir etkisi olmadığı sürece sorun yok.

Tablo 11 incelendiğinde katılımcılar; öğretim üyelerinin ders sırasında akıllı cep telefonlarını kullandıkları zamana ilişskin bakış açılarını; Kullanırlarsa rahatsızlık duymam ( $\mathrm{n}=14)$, acil durum dışında kullanmazlar $(\mathrm{n}=8)$, amaç dışı kullanımdan rahatsız olurum $(n=4)$, ders sürecine olumsuz bir etkisi olmadığı sürece sorun yok $(n=3)$ şeklinde belirtmiştir. Alanyazına bakıldığında öğretim elemanlarının ders sırasında cep telefonlarını kullanmalarına ilişkin öğrencilerin düşüncelerini ele alan araştırma sayısı çok azdır. Yine de akıllı telefonların ders sırasında kullanımının öğretmen, öğrenci ve içerik arasında etkileşim, iletişim ve işbirliği sağladığını ortaya koyan çalışmalara rastlamak mümkündür (Johnston 2016; Thomas ve Orthober 2011).

\section{Araştırmanın Sınırlılıkları}

Bu araştırmada lisansüstü öğrencilerine sorulan soruların cevapları kendini değerlendirme şeklinde olduğu için kişilerin beyanları ile sınırlıdır. Günlük olarak akıllı cep telefonu ile ne kadar meşgul olduğunu süre olarak hesaplayamayacağı gibi kendi doğası içinde rutinleşen davranışlarının farkında da olmayabilir. Ayrıca akıllı cep telefonu kullanımı deyince katılımcıların zihninde canlanan davranışlar farklılık gösterebilir. Bunun yanı sıra alanyazının da sıklıkla vurguladığı ve toplumda bireylerin de bağımlılık olarak gördüğü üzere derste cep telefonu kullanımı olumsuz bir davranış olarak algılanmaktadır. Bu algı da, öğrencilerin vermiş oldukları cevaplarında kullanım süresi ve amaçlarını hafife alma şeklinde yansımış olabilir. Alanyazında benzer durumlar görülmüştür. Duncan, Hoekstra ve Wilcox (2012), gerçek zamanlı sınıf etkinliklerde öğrencilerin cep telefonu kullanım süresini ders başına ortalama $3 \mathrm{kez}$ şeklinde raporlamalarına rağmen aslında 21 kez olarak gözlemlemiştir.

Bu araştırmanın sonuçlarını genellemek, araştırmanın çalışma grubu açısından sağlıklı olmayacaktır. Yukarıda da belirtildiği üzere bu araştırma tek bir eğitim bilimleri enstitüsüne kayıtlı olan aynı dönemde okuyan öğrencilerle sınırlıdır. Her ne kadar farklı branşlardaki öğrenciler çalışmaya dahil edilmiş olsa da farklı enstitülere kayıtlı öğrencilerle çalışma yinelendiğinde farklı sonuçlar elde etmek mümkündür.

\section{Sonuç}

Bulgulardan yola çıkarak öğrenci görüşleri özetlenecek olursa, bu araştırmaya katılan yüksek lisans öğrencilerinin daha çok derste geçen konu ya da terimi araştırmak, akademik araştırma, ders materyallerini takip etme, fotoğraf ya da sesli not özelliği ile ders notu alma, akran ve öğretim elemanı ile iletişim amaçlı kullanmalarının yanı sıra ders esnasında sıkıldıkları için ders ile ilgisi olmayan bildirimlerin ya da saatin kontrolü gibi eylemler için kullandıkları belirlenmiştir. Alan yazında benzer çalışmalar olmasına ve sınırlılıklarına rağmen bu çalışmanın özellikle yüksek lisans öğrencileri bağlamında ve Türk kültürünü yansıtması bakımından alanyazına katkı sağlayacağı düşünülmektedir. Her ne kadar alanyazında kuvvetli ölçüde ders sırasında ve dersle ilgili ders dışı etkinliklerde akıllı cep telefonu kullanımının bölünmelere neden olabileceği savunulsa da, uygun süre ve uygun araçların kullanımı öğrenme sürecine ve süresine önemli katkılar sağlamaktadır. Anshari vd., (2017) öğretim elemanlarının akıllı cep telefonlarının sınıfta kullanıma uygun şekilde öğrencilere cazip gelecek etkinlikler tasarlayıp uygun etkileşim ortamları oluştururlarsa, bu cihazların sınıf ortamında dikkat dağıtıcı etkisinin azalacağ görüşünü savunmaktadırlar. Felisoni ve Godoi (2018) de, akıllı cep telefonlarının güçlü öğrenme destekçisi şeklinde bir araç olma yönünün ortaya çıkarılabilmesi için uygun akademik ortamlar tasarlanması gerektiğini ve bu yönde yeni çalışmalar planlanması gerektiğinin altını çizmektedir. Burada bilinç düzeyinin ve kültürün etkisi yadsınamaz. Dolayısıyla öğrenme süreçleri ile ilgili bilinç düzeyi lisansüstü öğrencilerde daha yüksek olacağı için, bu öğrencilerle yapılan çalışmalar da daha olumlu sonuçlar ortaya koyacaktır. 21. yüzyılda öğretim elemanlarının karşılaştığı en büyük güçlüğün öğrencilerin mobil cihazlarla dış dünyaya bağlanmasının aşırı kolaylığı karşısında öğrencilerin ilgilerini ve derse bağlanmalarını sağlamaktır. Sınıfta fiziksel olarak var olan ancak zihinsel olarak ders dışı materyallerle mobil cihazlarına bağlanan öğrencilerin varlığı kaçınılmazdır (Kuznekoff, Munz ve Titsworth, 2015). Bu koşullarda en iyi çözüm, öğrencileri bu cihazlarıyla birlikte kabullenip, bu cihazların olumlu yanlarının eğitime entegre edilmesi için kültürel değişime ayak uydurmak olacaktır.

$\mathrm{Bu}$ araştırma durum çalışması olarak planlandığı için genellenmesi söz konusu değildir, bu nedenle yüksek lisans öğrencilerinin akıllı cep telefonlarını eğitim süreçlerinde kullanımına yönelik nicel çalışmalar planlanabilir. Ayrıca yine bu araştırmada katılımcıların görüşleri beyanlarına dayalı olarak incelenmiştir. Alanyazında da belirttiği üzere bazen akıllı cep telefonunun kullanımın farkında olmama ya da sık kullanımın toplum tarafından hoş karşılanmayacağı hissinden ötürü bu davranışı gizleme yoluna gidilebileceğinden, katılımcıların beyanları her 
zaman gerçek durumu ortaya koymayabilmektedir. Bu nedenle davranışların gözlemlenebileceği doğal süreçler üzerinde de araştırmaların planlanması alanyazına katkı sağlayacaktır. Bir başka çalışma konusu ise; öğretim elemanlarının akıllı cep telefonlarının eğitim süreçlerinde özellikle de ders sırasında kullanmasına ilişkin öğrencilerin görüşlerinin detaylı olarak incelenmesi de önemli bulgular sağlayacaktır. 


\section{References}

Abramova, O., Baumann, A., Krasnova, H., \& Lessmann, S. (2017). To Phub or not to Phub: Understanding OffTask Smartphone Usage and its Consequences in the Academic. Twenty-Fifth European Conference on Information Systems (ECIS), Guimarães, Portugal, 2017

Aljomaa, S. S., Al.Qudah, M. F., Albursan, I. S., Bakhiet, S. F., \& Abduljabbar, A. S. (2016). Smartphone addiction among university students in the light of some variables. Computers in Human Behavior, 61, $155 \mathrm{e} 164$. http://dx.doi.org/10.1016/ j.chb.2016.03.041.

Alarabiat, A., \& Al-Mohammad, S. (2015). The potential for Facebook application in undergraduate learning: A study of Jordanian students. Interdisciplinary Journal of Information, Knowledge, and Management, 10, 81103. Retrieved from http://www.informingscience.org/Publications/2283

Al Hamdani, D. S. (2014). A constructivist approach to a mobile learning environment. International Journal of Computer Applications, 93(4), 41-46.

Anshari, M., Almunawar, M. N., Shahrill, M., Wicaksono, D. K., \& Huda, M. (2017). Smartphones usage in the classrooms: Learning aid or interference?Education and Information Technologies, 22(6), 1-17.

Au, M., Lam, J., \& Chan, R. (2015). Social media education: Barriers and critical issues. In Technology in Education. Transforming Educational Practices with Technology, 199-205. Springer Berlin Heidelberg.

Baker, W. M., Lusk, E. J., \& Neuhauser, K. L. (2012). On the use of cell phones and other electronic devices in the classroom: Evidence from a survey of faculty and students. Journal of Education for Business, 87(5), 275289. doi:10.1080/08832323.2011.622814

Bolkan, S. \& Griffin, D.J. (2017). Students' use of cell phones in class for off-task behaviors: the indirect impact of instructors' teaching behaviors through boredom and students' attitudes, Communication Education, 66(3), 313-329, DOI:10.1080/03634523.2016.1241888 (http://dx.doi.org/10.1080/03634523.2016.1241888)

Bolliger, D. U., \& Shepherd, C. E. (2016). Instructor and adult learner perceptions of the use of Internet-enabled devices in residential outdoor education programs. British Journal of Educational Technology.

Bull, G., \& Thompson, A. (2004). Establishing a framework for digital images in the school curriculum. Leading and Learning with Technology, 31(8), 14-17.

Burton, A. (2015). Lecturers' experiences of using wikis to support student group work. Innovative Practice in Higher Education, 2(2).

Cambridge Dictionary Online, (2017). Phub Cambridge University Press, United Kingdom. Retrieved from https://dictionary.cambridge.org/dictionary/english/phub

Chen, S., \& Tzeng, J. (2010). College female and male heavy internet users' profiles of practices and their academic grades and psychosocial adjustment. Cyberpsychology, Behavior, and Social Networking, 13(3), $257-262$.

Chen, Q., \& Yan, Z. (2016). Does multitasking with mobile phones affect learning? A review. Computers in Human Behavior, 54, 34-42.

Corbeil, R. C., \& Valdes-Corbeil, M. E. (2007). Are you ready for mobile learning? Educause Review. Retrieved from http://er.educause.edu/articles/2007/1/are-you-ready-for-mobile-learning

Creswell, J.W. (2003). Research design: Qualitative, quantitative, and mixed methods approaches. California: Sage Publications Inc.

Csikszentmihalyi, M. (1990). Flow The psychology of Optimal Experience. New York: Harper, Perennial

Dahlstrom, E. (2012). ECAR study of undergraduate students and information technology, (Research Report), 2012. Educause) (Louisville, CO: ECAR).

Dahlstrom, E., \& Bichsel, J. (2014). ECAR study of undergraduate students and information technology, (Research Report), 2014. Educause (Louisville, CO: ECAR). 
Dietz, S. \& Henrich, C. (2014). Texting as a distraction to learning in college students. Computers in Human Behavior, 36, 163-167.

Duncan, D., Hoekstra, A., \& Wilcox, B. (2012). Digital devices, distraction, and student Performance: Does inclass cell phone use reduce learning? Astronomy Education Review, 11, 010108-1, 10.3847.

Echeverria, A., Nussbaum, M., Calderón, J. F., Bravo, C., Infante, C.Vàsquez, A. (2011). Face-to-face collaborative learning supported by mobile phones. Interactive Learning Environments, 19(4), 351-363. doi:10.1080/10494820903232943

Felisoni, D. D., \& Godoi, A. S. (2018). Cell phone usage and academic performance: An experiment. Computers \& Education, 117, 175-187.

Gökdaş, İ., Torun, F., \& Bağrıaçık, A. (2014). Öğretmen Adaylarının Cep Telefonlarını Eğitsel Amaçlı Kullanım Durumları ve Mobil Öğrenmeye İlişkin Görüşleri. [Teacher Candidates' Mobile Phones Educational Use Situations and Opinions on Mobile Learning] Adnan Menderes University Education Faculty Journal of Educational Sciences, 5(2), 43-61

García-Ormaechea, I., González, I., Duplá, M., Andres, E., \& Pueyo, V. (2014). Validation of the preverbal visual assessment (PreViAs) questionnaire. Early human development, 90(10), 635-638.

Hartnell-Young, E., \& Vetere, F. (2008). A means of personalizing learning: Incorporating old and new literacies in the curriculum with mobile phones. Curriculum Journal, 19(4), 283-292.

Hawi, N. S., \& Samaha, M. (2016). To excel or not to excel: Strong evidence on the adverse effect of smartphone addiction on academic performance. Computers \& Education, 98, 81-89.

Hwang, Ha S., Son, S. H., \& Choi, Y. J. (2011). Exploring factors affecting smart-phone addiction - characteristics of users and functional attributes. Korean Association for Broadcasting, 25(2), 277-313

Jacobsen, W. C., \& Forste, R. (2011). The wired generation: academic and social outcomes of electronic media use among university students. Cyberpsychology, Behavior, and Social Networking, 14(5), 275-280.

Johnston, K. A. (2016). The use, impact, and unintended consequences of mobile web-enabled devices in university classrooms. Issues in Informing Science and Information Technology, 13, 25-46. Retrieved from http://www.informingscience.org/Publications/3464

Johnston, K. A., Chen, M-M, \& Hauman, M. (2013). Changes in use, perception and attitude of Facebook and Twitter. Electronic Journal of Information Systems Evaluation (EJISE), 16(3), 200-210

Judd, T. (2014). Making sense of multitasking: the role of Facebook. Computers \& Education, 70, $194-202$.

Junco, R. (2012). In-class multitasking and academic performance. Computers in Human Behavior, 28(6), 22362243.

Junco, R., \& Cotten, S. R. (2011). Perceived academic effects of instant messaging use. Computers \& Education, 56(2), 370-378.

Just, M. A., Carpenter, P. A., Keller, T. A., Emery, L., Zajac, H., \& Thulborn, K. R. (2001). Interdependence of nonoverlapping cortical systems in dual cognitive tasks. NeuroImage, 14(2), 417-426.

Karpinski, A. C., Kirschner, P. A., Ozer, I., Mellott, J. A., \& Ochwo, P. (2013). An exploration of social networking site use, multitasking, and academic performance among United States and European university students. Computers in Human Behavior, 29, 1182-1192.

Kim, I., Jung, G., Jung, H., Ko, M., \& Lee, U. (2017). Let's FOCUS: Mitigating Mobile Phone Use in College Classrooms. Proceedings of the ACM on Interactive, Mobile, Wearable and Ubiquitous Technologies, 1(3), 63.

Kim, A. Y., Tak, H. Y., \& Lee, C. H. (2010). The development and validation of a learning flow scale for adults. Educational Psychology Research, 24(1), 39-59 
Kukulska-Hulme, A. (2007). Mobile usability in educational contexts: What have we learnt? The International Review of Research in Open and Distance Learning, 8(2).

Kuznekoff, J. H., Munz, S., \& Titsworth, S. (2015). Mobile phones in the classroom: Examining the effects of texting, Twitter, and message content on student learning. Communication Education, 64(3), 344-365.

Kwon, M., Lee, J.-Y., Won, W.-Y., Park, J.-W., Min, J.-A., Hahn, C., et al. (2013). Development and validation of a smartphone addiction scale (SAS). PloS One,8(2),

Lee, J., Cho, B., Kim, Y., \& Noh, J. (2015). Smartphone addiction in university students and its implication for learning. In Emerging issues in smart learning (pp. 297-305). Springer, Berlin, Heidelberg.

Lepp, A., Barkley, J. E., \& Karpinski, A. C. (2014). The relationship between cell phone use, academic performance, anxiety, and satisfaction with life in college students. Computers in Human Behavior, 31, 343350.

Lenhart, A., Ling, R., Campbell, S., \& Purcell, K. (2010). Teens and mobile phones. Washington, DC: Pew Internet \& American Life Project, 20.

Macmillan Dictionary Online, (2017) Phubbing Macmillan Publishers Limited, United Kingdom. Retrieved from http://macmillandictionary.com/buzzword/entries/phubbing.html

Markett, C., Sanchez, I. A., Weber, S., \& Tangney, B. (2006). Using short message service to encourage interactivity in the classroom. Computers and Education, 46, 280-293.

Marks, H. M. (2000). Student engagement in instructional activity: Patterns in the elementary, middle, and high school years. American Educational Research Journal, 37(1), 153-184

McCoy, B. (2013). Digital distractions in the classroom: Student classroom use of digital devices for nonclassroom related purposes. Journal of Media Education, 4(4), 5-14.

Mitchell, K. J., Finkelhor, D., \& Wolak, J. (2005). Protecting youth online: Family use of filtering and blocking software. Child abuse \& neglect, 29(7), 753-765.

Muñoz, C. F., \& García, F. G. (2016). The use of mobile phones as tools for access and knowledge exchange by students in Spain when studying: Access to leisure, persuasive and regulated schooling contents; key factors to take into consideration to plan targeted advertising campaigns. Prisma Social, (1), 190-208.

Nakamura, H., Hanamitsu, N., \& Minamizawa, K. (2015). A (touch) ment: a smartphone extension for instantly sharing visual and tactile experience. In Proceedings of the 6th Augmented Human International Conference, 223-224. ACM.

O'Bannon, B., Dunn, K., \& Park, Y. (2017, March). Validation of Mobile Phone Use in the Classroom Survey. In Society for Information Technology \& Teacher Education International Conference (pp. 1033-1041). Association for the Advancement of Computing in Education (AACE).

Olmstead, K. (2017). A third of Americans live in a household with three or more smartphones [monograph on the Internet]. Washington, DC: Pew Research Center.

Ophir, E., Nass, C., \& Wagner, A. D. (2009). Cognitive control in media multitaskers. Proceedings of the National Academy of Sciences, 106(37), 15583-15587.

Purcell, K., Heaps, A., Buchanan, J., \& Friedrich, L. (2013). How teachers are using technology at home and in their classrooms. Washington, DC: Pew Research Center's Internet \& American Life Project. Retrieved from http://pewinternet.org/Reports/2013/Teachers-and-technology

Roodt, S., de Villiers, C., Johnston, K., Ophoff, J., \& Peier, D. (2014). YouTube as an academic tool for ICT lecturers. Proceedings of the e-Skills for Knowledge Production and Innovation Conference 2014.

Rosen, L. D., Carrier, L. M., \& Cheever, N. A. (2013). Facebook and texting made me do it: media-induced taskswitching while studying. Computers in Human Behavior, 29(3), 948e958.

Ruggiero, D., \& Mong, C. J. (2015). The teacher technology integration experience: Practice and reflection in the classroom. Journal of Information Technology Education: Research, 14, 161-178. 
Smith, A., McGeeney, K., Duggan, M., Rainie, L. \& Keeter, S. (2015). US smartphone use in 2015. Pew research Center. Retrieved from http://www.pewinternet.org/files/2015/03/PI_Smartphones_0401151.pdf.

Tesch, F., Coelho, D., \& Drozdenko, R. (2011). We have met the enemy and he is us: Relative potencies of classroom distractions. Business Education Innovation Journal, 3(2), 13-19.

Tindell, D. R., \& Bohlander, R. W. (2012). The use and abuse of cell phones and text messaging in the classroom: a survey of college students. College Teaching, 60(1), 1-9.

Thomas, K., \& Orthober, C. (2011). Using text-messaging in the secondary classroom. American Secondary Education, 39(2), 55-76.

Thomas, K., O'Bannon, B. W, \& Britt, V. G. (2014). Standing in the schoolhouse door: Teacher perceptions of mobile phones in the classroom. Journal of Research on Technology in Education, 46(4), 373-395.

TÜIK, (2017) Hanehalkı Bilişim Teknolojileri Kullanım Araştırması, [Household Information Technologies Usage Survey] 2017. Retrieved from http://www.tuik.gov.tr/VeriBilgi.do?alt_id=1062

Wang, Y., Wu, M., \& Wang, H. (2009). Investigating the determinants and age and gender differences in the acceptance of mobile learning. British Journal of Educational Technology, 40(1), 92-118. doi:10.1111/j.14678535.2007.00809.x.

Wood, E., Zivcakova, L., Gentile, P., Archer, K., De Pasquale, D., \& Nosko, A. (2012). Examining the impact of off-task multitasking with technology on real-time classroom learning. Computers \& Education, 58, 365-374.

Yoon, J. Y., Moon, J. S., Kim, M. J., Kim, Y. J., Kim, H. A., Heo, B. R., Kim, J. E., Hong, H. J. (2011). Smartphone addiction and health problem on university students. Journal of Korean Association for Crisis and Emergency Management, 3(2), 92-104.

Yıldırım, K., Yaşar, Ö. ve Murat, D. (2016). Öğretmen ve Öğrenci Görüşleri Temelinde Akıllı Telefonların Eğitim Ögretim Ortamlarında Kullanılmasının ve Etkilerinin İncelenmesi. [Based On The Views Of Teachers and Students Analysing The Usage Of Smartphones In Teaching and Learning Environments and Effects] International Journal of Education Science and Technology, 2(2), 72-84. 